\title{
Bypassing drug resistance by triggering necroptosis: recent advances in mechanisms and its therapeutic exploitation in leukemia
}

\author{
Xianbo Huang ${ }^{1}$, Feng Xiao ${ }^{1,2}$, Yuan $\mathrm{Li}^{4}$, Wenbin Qian ${ }^{1,2}$, Wei Ding ${ }^{3^{*}}$ and Xiujin Ye ${ }^{1^{*}}$ (D)
}

\begin{abstract}
Resistance to regulated cell death is one of the hallmarks of human cancers; it maintains cell survival and significantly limits the effectiveness of conventional drug therapy. Leukemia represents a class of hematologic malignancies that is characterized by dysregulation of cell death pathways and treatment-related resistance. As the majority of chemotherapeutic and targeted drugs kill leukemia cells by triggering apoptosis, the observed resistance indicates the need for novel therapeutic strategies to reactivate nonapoptotic cell death programs in refractory leukemia. Necroptosis is a regulated form of necrosis that is precisely modulated by intracellular signaling pathways and thus provides potential molecular targets for rational therapeutic intervention. Indeed, accumulating evidence indicates that many current antitumor agents can activate necroptotic pathways and thereby induce leukemia cell death. Elucidation of the complete regulatory mechanism of necroptosis is expected to accelerate the development of novel therapeutic strategies for overcoming apoptosis resistance in leukemia. Here, we review the latest research advances in the regulatory mechanisms of necroptosis and summarize the progression of necroptosis-based therapeutic strategies in leukemia.
\end{abstract}

Keywords: Necroptosis, Leukemia, Apoptosis resistance, RIPK1, RIPK3, MLKL

\section{Background}

A delicate balance between cell proliferation and death is essential for maintaining the normal physiological function of organisms. Dysregulation of regulated cell death (RCD) contributes to a number of human diseases, including cancer. During tumorigenesis, neoplastic cells become resistant to RCD, which results in unlimited cell growth and the acquisition of additional oncogenic mutations $[1,2]$. Recently, induction of cell death has been considered the most important mechanism of various antitumor agents. Thus, targeting cell death signaling is an attractive strategy for developing novel anticancer therapies [3].

\footnotetext{
* Correspondence: 1181010@zju.edu.cn; yxjsunny@zju.edu.cn

${ }^{3}$ Department of Pathology, the First Affiliated Hospital, College of Medicine,

Zhejiang University, 79\# Qingchun Road, Hangzhou 310003, China

'Department of Hematology, the First Affiliated Hospital, College of

Medicine, Zhejiang University, 79\# Qingchun Road, Hangzhou 310003, China

Full list of author information is available at the end of the article
}

In recent years, major developments have been made in the identification and characterization of cell death programs, and various forms of RCD, including apoptosis, autophagy and necroptosis, have been discovered and evaluated. Apoptosis is the first identified and best-studied form of RCD, and analyses of this process have led to the development of multiple anticancer drugs that reactivate apoptosis to kill tumor cells, including leukemia cells $[4,5]$. However, inducing apoptosis by various antitumor agents is often limited by therapeutic resistance due to the impairment or deficiency of apoptotic pathways [6]. Thus, identification of more thoughtful therapies that target alternative forms of RCD is the main focus in cancer research.

Necrosis was previously considered to be a random and passive process that required no specific molecular events. However, a regulated type of necrosis (so-called necroptosis) was recently discovered via identification of chemical inhibitors of necrotic cell death (necrostatins), 
which underlines its regulated nature [7, 8]. Receptorinteracting protein kinase 1 (RIPK1) is a critical regulator of necroptosis. RIPK3 acts as a downstream mediator of RIPK1 [9], and mixed lineage kinase domain-like (MLKL) is regarded as the key player in necroptosis execution [10].

Leukemia refers to a variety of malignant clonal diseases of hematopoietic stem cells that can induce death and is one of the top ten most dangerous causes of mortality for human beings [6]. In recent years, the survival rates of leukemia have significantly improved due to the development of individual chemotherapy and biological targeted therapy. However, the increasing rate of treatment-related resistance in leukemia remains a major challenge for researchers [11]. Given the rising significance of necroptosis in cancer, a better understanding of its detailed regulatory mechanisms is needed for the development of drugs to trigger necroptosis in leukemia cells, especially those with apoptosis resistance. A review of necroptosis and its relevance in leukemia is therefore urgently needed. In this review, we will discuss the regulatory mechanism of necroptosis in detail. We will also summarize the research progress made in induction of necroptosis in leukemia cells.

\section{Main text}

\section{Mechanisms and regulation of necroptosis Characteristics of necroptosis}

Necroptosis is a novel characterized form of cell death that has several distinctive characteristics compared to other types of cell death, particularly apoptosis. Necroptosis is also called "programed necrosis" and shares some morphological features with necrosis, including early loss of plasma membrane integrity, translucent cytosol, increased cell volume and swollen organelles [9, 12]. Unlike necroptotic cells, apoptotic cells lack these features and are characterized by plasma membrane blebbing, cell shrinkage, chromatin condensation, cleavage of chromosomal DNA and formation of apoptotic bodies without rupture of the plasma membrane (Fig. 1) $[13,14]$. At the biochemical level, apoptosis requires caspase activation and is mediated by the interplay of Bcl-2 family proteins or activation of death receptors. Apoptosis can be blocked by pan-caspase inhibitors (e.g., zVAD-fmk) or expression of viral inhibitors of caspases (e.g., CrmA) [13, 14]. Necroptosis is caspase-independent and controlled by RIPK1, RIPK3 and MLKL, which can be blocked by various specific small molecule inhibitors (Fig. 1) [7, 8, 15]. Another key feature of necroptotic cells is the release of damage-associated molecular patterns (DAMPs) and cytokines/chemokines due to the permeabilization of the plasma membrane, which can subsequently trigger robust inflammation and an immune response [16, 17]. In contrast, apoptotic cells and/or apoptotic bodies are engulfed and then dissolved via phagocytosis by antigen-presenting cells (APCs) or by neighboring cells [18], which do not typically induce a strong immune response (Fig. 1) [8].

Despite these distinctive features, the molecular mechanism of necroptosis is believed to be closely related to other forms of cell demise (e.g., apoptosis and autophagy) [19], which prompted us to explore the regulation and relative contributions of different cell death modes. Apoptosis and necroptosis share several upstream signaling elements [20]. Therefore, how does a cell decide whether to undergo apoptosis or necroptosis? Current views suggest that the choice of cell death is determined by a variety of factors, including stimuli, cell type, genetic background and the intracellular environment. Usually, apoptosis is the preferred mode of death for cells, and necroptosis functions as an alternative mechanism to eliminate stressed cells or infected cells that fail to undergo apoptosis [21]. However, necroptosis can also play a dominant role under certain circumstances, such as abnormal metabolism, genetic mutations, viral infection and exposure to some cytotoxic antitumor drugs [22-24]. More often, it is a continuous process from apoptosis to necroptosis [25, 26]. Intensified death signals and increased stress levels can switch cell death from apoptosis to necroptosis [27]. Autophagy is a lysosomal degradation system that engulfs the cytoplasm and organelles for cellular renovation and homeostasis, and it may also participate in crosstalk with necroptosis [19]. Sometimes, autophagy can serve as a scaffold or pivotal site to mediate the formation of necrosome complexes, which finally lead to MLKL phosphorylation and cell necroptosis stimulation [27, 28]. The interrelationship between necroptosis and other cell death pathways is complicated and should be further explored.

\section{Triggers of necroptosis}

Various stimuli can lead to the initiation of necroptosis [20]. Ligand-receptor interactions are extrinsic pathways for the initiation of necroptosis. Recent studies have shown that necroptosis can be induced by the engagement of death receptors (DRs) in the TNF superfamily, including TNF receptor-1 (TNFR1), FAS (also known as CD95 or APO-1), TNF-related apoptosis-inducing ligand receptor 1 (TRAILR1, also known as DR4), and TRAILR2 (also known as DR5, APO-2, TRICK or KILLER). These receptors trigger necroptosis via their common cytoplasmic death domains (DDs) [23, 29]. In addition to DRs, other types of stimuli, including engagement of Toll-like receptors 3 and 4 (TLR3, TLR4) by lipopolysaccharides (LPS), pathogen-derived double-stranded DNA/RNA (dsDNA/RNA), T-cell receptor stimulation, type I and type II interferons (IFNs), virus infection via the z-DNA 


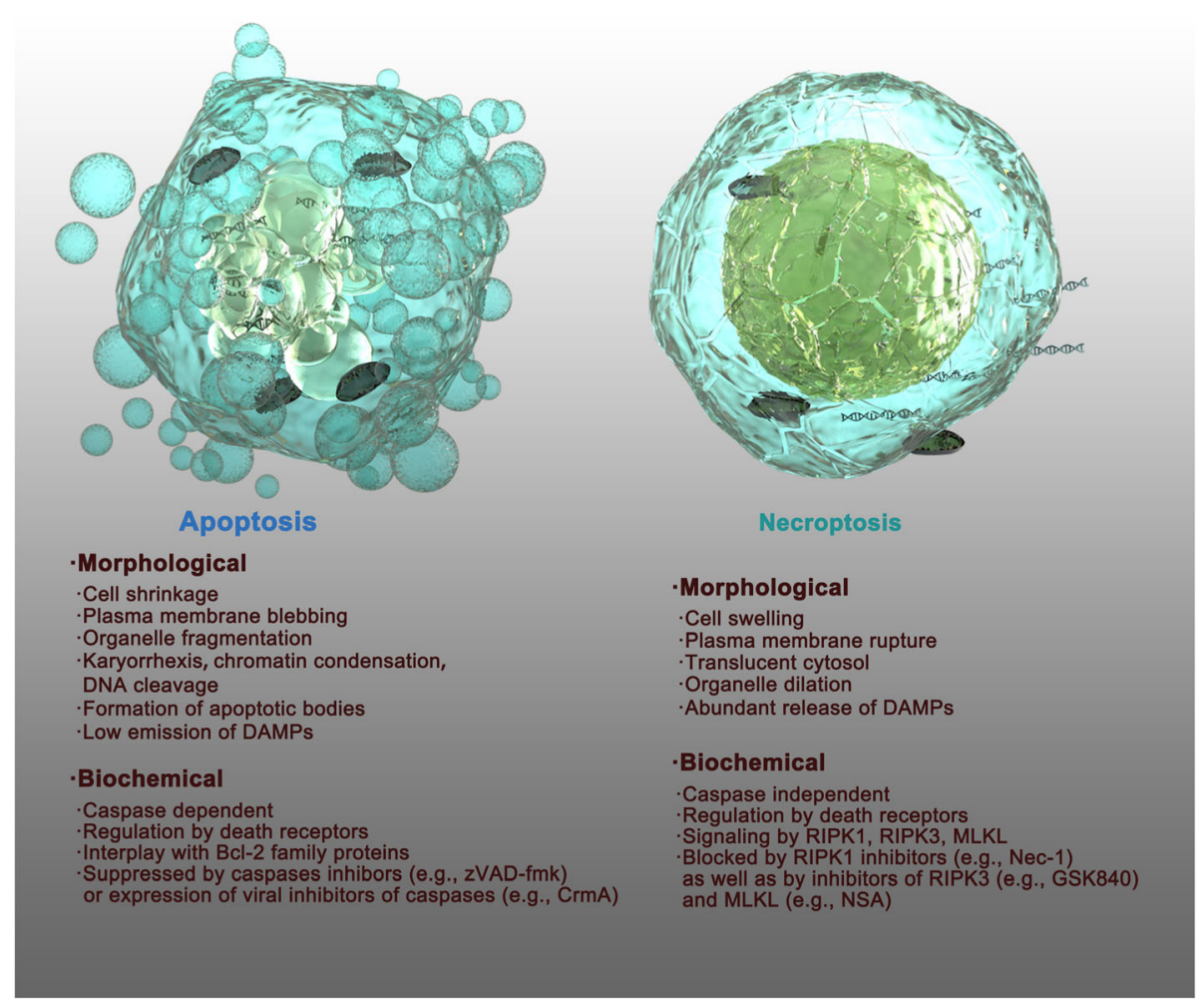

Fig. 1 Schematic diagram describing the morphological and biochemical differences between apoptosis and necroptosis. Apoptotic cells are characterized by plasma membrane blebbing, cell shrinkage, organelle fragmentation, chromatin condensation, cleavage of chromosomal DNA and the formation of apoptotic bodies without rupture of the plasma membrane, and apoptotic cells show low emission of DAMPs. Necroptotic cells share some morphological features to apoptotic cells, resembling necrosis including cell swelling, plasma membrane rupture, translucent cytosol, and organelle dilation, and necroptotic cells are associated with the abundant release of DAMPs. At the biochemical level, apoptosis and necroptosis have different intracellular molecular mechanisms as described, and they can be specifically blocked by various types of inhibitors

sensor DNA-dependent activator of IFN regulatory factors (DAI) and genotoxic stress, can trigger necroptosis [23, 30-33]. Several other types of stimuli, including retinoic acid-inducible gene I (RIG-I), mitochondrial antiviral signaling protein (MAVS), DAMPs, protein kinase $\mathrm{R}$ (PKR) complexes, nucleotide-binding and oligomerization domain (NOD)-like receptors (NLRs) and some antitumor agents, also result in necroptosis $[34,35]$. These triggers are considered to individually or jointly induce necroptosis in complicated physiological or pathological conditions. It is beyond the scope of this review to list all the stimuli related to necroptosis from the current literature; therefore, we summarize the above triggers, which are most likely important in necroptosis induction.

\section{Initiation of necroptosis: necrosome formation}

Canonical necrosomes One of the most extensively studied and best-characterized signaling mechanisms of necroptosis is the binding of TNF- $\alpha$ to TNFR1, which subsequently recruits a series of intracellular proteins to form complexes involved in proinflammatory and survival signaling (complex I), apoptosis (complex II) and necroptosis (necrosome) $[8,36,37]$. Notably, apoptosis pathway inactivity or deficiency (e.g., when caspase-8 or apoptosis inhibitors [IAPs] are downregulated or inhibited) must prevail for TNFR1-mediated necroptosis to ensue [38].

Under certain conditions, such as infection or tissue impairment, TNF- $\alpha$ binds to and stimulates TNFR1 through the preligand assembly domain of the extracellular portion of TNFR1 and then triggers its trimerization [39]. Upon activation, TNFR1 can recruit diverse intracellular proteins and induce the formation of a membrane-bound complex called complex I. Complex I consists of TNF- $\alpha$ receptor associated death domain (TRADD), E3 ubiquitin ligases TNF- $\alpha$ receptor associate factor 1,2 and 5 (TRAF1, 2, 5), cellular inhibitor of apoptosis protein-1 and -2 (cIAP1/2) and RIPK1 (Fig. 2) [40-42]. In this complex, RIPK1 is polyubiquitinated by the ubiquitin ligase cIAP1/2 and other E3 ubiquitin ligases, and the polyubiquitin chain contributes to the recruitment of a number of proteins, such as transforming growth factor $\beta$-activated kinase 1 (TAK1), transforming growth factor $\beta$-activated kinase binding protein 2 and 3 (TAB2, 3), nuclear factor kappa B essential modulator 


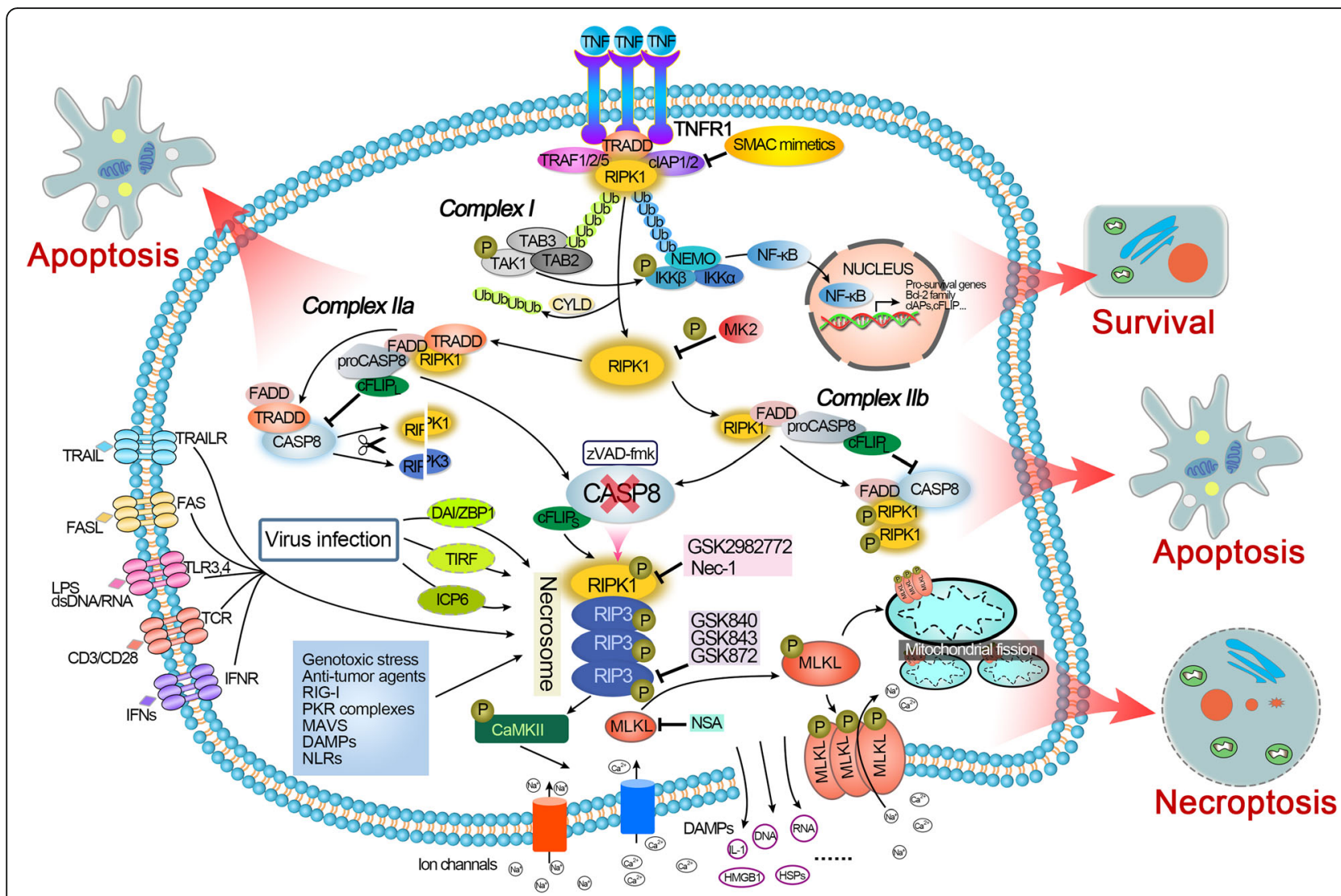

Fig. 2 A schematic overview of the molecular signaling pathways involved in necroptosis. Upon TNF-a stimulation, activated TNFR1 recruits various downstream proteins, including RIPK1, to form prosurvival complex I, resulting in RIPK1 polyubiquitination and subsequently facilitating NF-KB signaling to prevent cell death (see text). Phosphorylation of RIPK1 by MK2 can also limit RIPK1 activation and the subsequent assembly of the death complex through the IKKa/ $\beta$ independent way. Inhibition of CIAPs (by Smac or Smac mimetics) leads to CYLD-mediated deubiquitination of RIPK1 and its dissociation from TNFR1, resulting in the formation of different prodeath complexes (complex Ila, IIb and the necrosome). Complex lla contains TRADD and can be formed independently of the scaffold and kinase function of RIPK1. In contrast, complex Ilb lacks TRADD and requires RIPK1 kinase activity for cell death induction. Complex lla and Ilb activate caspase-8, leading to apoptotic cell death. If caspase-8 activity is blocked, RIPK1 will bind to RIPK3 to form necrosomes and promote RIPK3 autophosphorylation and activation. Activated RIPK3 is currently known to function via at least two downstream effectors: MLKL and CaMKII, which are effector molecules leading to necroptosis through multiple mechanisms. Other stimuli, including FasL, TRAIL, CD3/CD28, LPS, dsDNA/RNA and IFNs, can stimulate their corresponding receptors to activate necrosomes to promote necroptosis. Infection with some viruses directly activates RIPK3 through DAI, TIRF or ICP6. Anticancer agents, genotoxic stress and some other factors can also trigger RIPK1/RIPK3-dependent necroptosis. Necroptosis is inhibited experimentally by specific inhibitors of RIPK1, RIPK3 and MLKL, as shown above

(NEMO), and IkB kinase $\alpha / \beta(\mathrm{IKK} \alpha / \beta)$, and subsequently facilitates the nuclear factor $\kappa \mathrm{B}(\mathrm{NF}-\mathrm{kB})$ cell survival pathways [43-45] (Fig. 2). This change drives the expression of downstream proteins directly involved in apoptosis inhibition, such as B-cell lymphoma 2 (Bcl-2) family members, the caspase- 8 inhibitor FLICE-like inhibitory proteins (cFLIP) and cIAPs [46-48]. cFLIP, a catalytically inactive homolog of caspase-8, was reported to be an important regulator of apoptosis and necroptosis [49]. The long cFLIP isoform $\left(\mathrm{cFLIP}_{\mathrm{L}}\right)$ binds to pro-caspase- 8 and forms the caspase- $8 / \mathrm{cFLIP}_{\mathrm{L}}$ heterodimer (Fig. 2). For this reason, $\mathrm{CFLIP}_{\mathrm{L}}$ reduces oligomerization of caspase- 8 at FADD and finally inhibits apoptosis, but the caspase- 8 still maintains sufficient proteolytic activity $[50,51]$. Meanwhile, the heterodimer causes the cleavage of the necroptosis core regulators RIPK1 and RIPK3, thus inhibiting necroptosis $[52,53]$. Therefore, the absence of $\operatorname{cFLIP}_{\mathrm{L}}$ can induce caspase-dependent apoptosis or caspase-independent necroptosis. However, another short type of cFLIP isoform (cFLIP $)$ can combine with and inactivate caspase- 8 , which allows the activation of RIPK $1 / 3$ and thus leads to necroptosis (Fig. 2) [54]. Therefore, we believe that ubiquitylated RIPK1 can prevent cell death via activating survival pathways. Hence, complex I is a crucial checkpoint for cell survival and death. More recently, an additional transcription-independent checkpoint has been shown to modulate the contribution of RIPK1 to cell demise. RIPK 1 phosphorylation by IKK $\alpha / \beta$ in complex I prevents RIPK1 kinase-dependent formation of the death complex [55]. RIPK1 is also a direct substrate 
of MAPK-activated protein kinase 2 (MK2). Phosphorylation of RIPK1 by MK2 can limit cytosolic activation of RIPK1 and the subsequent assembly of the death complex that drives RIPK1-dependent apoptosis and necroptosis, representing a mechanism that is distinct from the regulatory function of RIPK1 mediated by IKK $\alpha / \beta$ [56-58].

The degradation of cIAPs caused by second mitochondria-derived activator of caspases (Smac) or synthetic Smac-mimetics [47, 59-61] can reduce RIPK1 ubiquitination via deubiquitinase enzymes such as cylindromatosis (CYLD), resulting in RIPK1 dissociation from the plasma membrane and its conversion from a prosurvival into a pro-death protein $[62,63]$. RIPK1 deubiquitination leads to the suppression of NF- $\mathrm{KB}$ and reduction of cFLIP and simultaneously promotes the formation of the cytosolic pro-cell death complex (complex II, also called 'ripoptosome') (Fig. 2) [54, 55]. Different types of complex II can be distinguished (IIa and IIb), depending on the composition and activity of the proteins therein. Complex IIa is formed after dissociation of TRADD from TNFR1 and results in the recruitment of downstream RIPK1, FAS-associated death domain protein (FADD) and pro-caspase-8, leading to caspase-8 activation. The activated caspase- 8 then cleaves and inactivates RIPK1/RIPK3 and subsequently induces a type of RIPK1-independent apoptosis (Fig. 2) [8, 52, 54, 64, 65]. In conditions where cIAPs, TAK $1, \mathrm{NEMO}$, and IKK $\alpha / \beta$ are inhibited or absent, a similar complex (complex IIb) is formed without TRADD (Fig. 2), where RIPK1 kinase activity is required for caspase- 8 activation and promotes RIPK1 kinase activity-dependent apoptosis [66-69]. In some cell types or conditions, the levels of RIPK3 and MLKL are sufficiently high; caspase- 8 activity is reduced, blocked or absent; and RIPK1 in complex II will recruit RIPK3. Then, a series of auto- and cross-phosphorylation reactions occur between RIPK1 and RIPK3 through their respective homotypic interaction motif (RHIM) domains, evolving to form a functional signaling complex called the necrosome $[65,70]$. In necrosomes, activated RIPK3 recruits and phosphorylates the downstream pseudokinase MLKL, stimulating its oligomerization and translocation to the plasma membrane to trigger necroptosis (Fig. 2) $[10,71,72]$. The complex interaction between these cellular conditions forms the basis for either allowing or preventing the execution of necroptosis. The successful initiation of necroptosis via TNF- $\alpha$ /TNFR1 signaling is often based on the downregulation or inhibition of cIAPs and caspase-8 [72-74].

Noncanonical necrosomes In classical necroptosis, necrosomes are formed via the RIPK1-RIPK3 activation model through the RHIM domain. Phosphorylation of RIPK1 and RIPK3 at the kinase domain induces RHIM-mediated interactions, which result in the formation of amyloid-like filamentous signaling complexes $[65,70,75]$ and culminate with necroptosis. In addition to RIPK1/3, other proteins such as TRIF (TIR-domain-containing adapter-inducing interferon- $\beta$; also known as TICAM1, TIR domain-containing adapter molecule 1), DAI (DNA activator of interferon; also known as ZBP1, Z-DNA binding protein 1) and ICP6 (viral ribonucleotide reductase large subunit) also have RHIM domains. These RHIM domain-containing proteins may function as a platform allowing RIPK3 oligomerization, autophosphorylation and activation through a RIPK1-independent mechanism that often involves an RHIM-RHIM interaction (Fig. 2) [30, 76-79]. Hence, they can form the necrosome, which is considered a noncanonical necrosome. For example, upon cytomegalovirus (CMV) infection in some cell types, DAI can activate RIPK3 directly via an RHIM-RHIM interaction but does not involve RIPK1 kinase activity [80]. After herpes simplex virus 1 (HSV-1) infection, the viral protein ICP6 interacts with RIP3 through a RHIM-RHIM interaction to trigger necroptosis and host defense, which do not require RIPK1 $[79,81]$. Similarly, TLR3 and TLR4 initiate RIPK1-independent necroptosis mediated by the TRIF adaptor through the formation of the so-called TRIF-RIPK3 necrosome [30, 76]. Thus far, it is unclear how exactly RIPK3 is activated downstream of these RHIM domain-containing proteins. TRIF is an adapter that responds to the activation of TLRs, such as RIPK1 and RIPK3, and it is also a cleavage substrate for caspase-8. Recent studies have shown that inhibition of RIPK1 does not affect TLR3-mediated necroptosis. Unlike RIPK1, TRIF does not have kinase activity, indicating that the mechanism by which TRIF stimulates RIPK3 is different from the RIPK1-mediated RIPK3 activation [30]. Wang X et al. demonstrated that HSV-1 with an ICP6 deletion failed to induce effective necroptosis in infected cells. Furthermore, ectopic expression of ICP6, but not RHIM mutant ICP6, directly activated RIPK3/MLKL-mediated necroptosis [79]. Other studies have revealed that the perinatal lethality of RHIM-deficient RIPK1 knock-in mice can be rescued by DAI deficiency, which will prevent DAI/RIPK3/MLKL-dependent necroptosis during development. These findings indirectly proved that DAI will bind and activate RIPK3 to form a DAI-RIPK3 necrosome, which will participate in nonclassic necroptosis [82, 83].

\section{Execution of necroptosis: MLKL activation}

Recent studies have identified the pseudokinase MLKL as a major executioner of necroptosis [10]. Following stabilization of the RIPK1-RIPK3 complex, MLKL is recruited to form a functional necrosome [10, 72, 84]. Normally, MLKL remains inactive as a monomer in the cytosol [72]. Once the necrosome forms, the activated 
RIPK3 recruits and phosphorylates the downstream MLKL at Ser345, Ser347, Ser358 and Thr357 and the mouse MLKL at Ser352 and Thr349 within the MLKL activation loop [10, 72, 85], which results in an open conformational shift of MLKL and exposure of its four-helical bundle domain $[10,86]$. Destabilization of the structure promotes MLKL oligomerization, resulting in the translocation of the MLKL oligomer from the cytosol to the plasma membranes (as well as to intracellular membranes), where it compromises the membrane integrity to promote necroptotic death (Fig. 2) [87-89]. Several hypotheses have been proposed to explain the mechanism of MLKL oligomer targeting to the cellular membrane and induction of cell death. Some have suggested that the MLKL oligomer can directly form a pore in the plasma membrane after binding to negatively charged phospholipids, subsequently causing necrotic membrane disruption. Lipids play a crucial role in MLKL membrane targeting. Phosphorylated MLKL forms an oligomer that can interact with phosphatidylinositol phosphates (PIPs, mostly including $\mathrm{PI}[5] \mathrm{P}$ and $\mathrm{PI}[4,5] \mathrm{P}_{2}$ ) on the inner surface of the plasma membrane through a low affinity site in its N-terminal bundle domain [88, 89]. This process may result in different modes of membrane permeabilization (including carpet, barrel stave and toroidal) [90]. Interestingly, necroptosis can be blocked by interfering with the formation of $\mathrm{PI}(5) \mathrm{P}$ or $\mathrm{PI}(4,5) \mathrm{P}_{2}$ [88]. The relocalization of MLKL oligomers to the plasma membrane also induces ion-pore dysregulation (including $\mathrm{Na}^{+}$and $\mathrm{Ca}^{2+}$ influx) through association with ion channels, which accelerates membrane permeabilization and damage due to the increase in intracellular osmotic pressure and nanopore formation in the plasma membrane (Fig. 2) [91-94]. Alternatively, RIPK3 can activate $\mathrm{Ca}^{2+}$-calmodulin-dependent protein kinase II (CaMKII) independently of MLKL, which in turn induces an ion influx by activating multiple ion channels (Fig. 2) [95]. Nonetheless, it is still unclear whether the observed ion influx is a consequence or the cause of necroptotic cell death [76].

MLKL oligomers also target the mitochondrial membrane and induce mitochondrial permeability transition (MPT) alteration, which can subsequently cause mitochondrial disruption [96]. Mitochondrial disruption induces ATP depletion and excessive reactive oxygen species (ROS) production to contribute to cell death [97]. ROS are an important effector during necroptotic cell death and can kill cells in a positive feedback loop $[12,96,98]$. Although we have listed various execution mechanisms downstream of necrosomes, the full necroptotic cell death process remains to be elucidated.

\section{Necroptosis and inflammation: DAMPs release}

Necroptosis is closely associated with inflammation. The final stage of cell necroptosis, known as propagation, can lead to robust inflammation mainly through massive release of intracellular contents [17]. The majority of these cellular components are collectively described as DAMPs (Fig. 2) [99]. In contrast, apoptosis is generally nonimmunogenic because of plasma membrane shrinkage and orderly intracellular content disassembly, which results in nearly no release of DAMPs $[16,17]$. DAMPs represent a collection of cellular components and molecules that are exposed or released by dying, injured or stressed cells, which act as a key contributor to triggering the inflammatory response. Generally, DAMPs include cytokines and alarmins that are released mainly by dying cells, such as the interleukin-1 family cytokines and S100 proteins. Additionally, several cellular components that are originally functional and nonimmunological can be released by damaged cells to act as DAMPs. These include histones and HMGB (high-mobility group protein) family members, DNA and RNA outside of nuclei or mitochondria, ribonucleoproteins, heat-shock proteins, purine metabolites, F-actin, calreticulin, etc. $[17,99,100]$. The release of DAMPs from the disintegrating cells suffering necroptosis is generally believed to be the primary mechanism of the inflammatory response mediated by MLKL-necrosome activation and MLKL oligomer insertion in the plasma membrane $[17,101]$. This hypothesis has been supported by evidence that specific DAMPs are released by necroptotic cells, which are important mediators of inflammation [102]. These necroptosis-specific DAMPs include cytosolic lactate dehydrogenase and lysosomal hexosiminidase, as well as organ-specific proteins, such as heart or kidney creatine kinase and liver alanine aminotransferase [102]. Based on these findings, we speculate that necroptosis-specific DAMPs can be used for diagnostic biomarker development compared with other types of regulated necrotic cell death events, such as pyroptosis or ferroptosis [8]. To date, the full range of the specific DAMPs as mediators of necroptosis-induced inflammation requires further investigation.

\section{Detection and pharmacological targeting of necroptosis}

Due to a lack of specific molecular markers of necroptosis, a combination of approaches is often required to distinguish necroptosis from other cell death modalities. Transmission electron microscopy (TEM) or H\&E staining is widely used to provide morphological evidence of necrosis [103]. PI permeability, loss of mitochondrial membrane potential (MMP), production of intracellular ROS, depletion of ATP and other factors are the detectable characteristics of necroptosis, but they do not distinguish necroptosis from other types of cell death [103, 104]. RIPK1, RIPK3 and MLKL are usually regarded as essential biochemical markers of necroptosis. Their activation can be detected by changes in the protein expression and 
phosphorylation status using immunoblotting or immunostaining $[105,106]$. The formation of necrosome complexes can be observed by RIPK1/RIPK3 and RIPK3/ MLKL interactions using immunoprecipitation or other methods [75]. The existence of RIPK1, RIPK3 and MLKL is necessary for necroptosis execution. We can use various approaches, such as gene knockout, siRNA/shRNA knockdown, small-molecule inhibitors and kinase-dead or interacting domain-deficient mutants, to further determine the role of these molecules in necroptosis. Researchers have made major efforts to develop small-molecule inhibitors that target these proteins (Fig. 1). Necrotatin-1 (Nec-1) was the first RIPK1 inhibitor identified by Yuan J's group [7], and it has recently been widely used in the study of necroptosis. However, Nec-1 is not just the inhibitor of RIPK1 but also a potent inhibitor of indoleamine 2,3-dioxygenase (IDO), which is an immunomodulatory enzyme that regulates the formation of kynurenine [107]. Thus, interpretation of the results obtained with Nec-1 should always be used with caution. Additionally, GSK2982772 is a newly identified RIPK1 inhibitor detected by chemical screening [108]. The RIPK3 inhibitors GSK840, GSK843, GSK872 [30, 109] and dabrafenib [110] and the MLKL inhibitor necrosulfonamide (NSA) [72] are also used for research. In addition, the anticancer drugs ponatinib and pazopanib were recently found to inhibit both RIPK1 and RIPK3 (Fig. 2) [111]. Other types of RIPK1/RIPK3/MLKL inhibitors are still under development.

\section{Therapeutic induction of necroptosis in leukemia cells}

Impairment of cell death pathways and evasion of RCD, especially apoptosis, are hallmarks of various cancers, including leukemia, that contribute to tumor initiation, progression and treatment resistance $[1,112]$. Resistance to chemotherapy is currently a major problem in cancer treatment, and it is frequently associated with failure of tumor cells to undergo apoptosis [1]. Therefore, there is an urgent need to develop new therapies to promote cell death in cancers. Necroptosis, as a recently identified form of nonapoptotic RCD, may offer an alternative option to trigger apoptosis-resistant cancer cell death. Elucidation of the signal transduction pathways of necroptosis in cancer cells is expected to help develop novel strategies to trigger necroptosis in leukemia therapy. Thus far, accumulating work has proven that the induction of necroptosis may overcome drug resistance in cancers. In the following paragraphs, we provide a brief summary of findings regarding necroptosis in several major types of leukemia (Table 1).

\section{Acute myeloid leukemia}

Acute myeloid leukemia (AML) is an aggressive disease that represents the most frequent malignant myeloid neoplasm in adults [113]. Despite current aggressive treatment strategies, the prognosis of AML is still poor due to its low survival and high relapse rate [113]. Thus far, most current therapies exert their antileukemic effects by promoting apoptosis in AML cells [114]. Apoptosis-resistant AML cells usually fail to undergo apoptosis due to the impairment of related pathways [114], and thus, induction of nonapoptotic cell death, such as necroptosis, is needed to overcome the treatment resistance and improve the outcomes of AML.

IAP proteins represent a family of antiapoptotic proteins that block RCD through various mechanisms [115]. As we described before, the IAP family members cIAP1/ 2 can act as E3 ubiquitin ligases that mediate ubiquitination of RIPK1 and contribute to canonical NF-kB signaling activation, which leads to cell survival [43]. Once deubiquitinated, RIPK1 can promote apoptosis or necroptosis based on the caspase-8 activity [40]. Another IAP, membrane X-linked inhibitor of apoptosis (XIAP), is known to block apoptosis by inhibiting caspase- 9 and $-3 /-7$ activation [116]. Therefore, the IAPs may be an important node that determines cell survival or death. IAPs can be neutralized by Smac, which is released from the mitochondrial intermembrane space into the cytosol during apoptosis [115]. Therefore, Smac can cause cell death via two pathways: a caspase-dependent apoptotic pathway or a caspase-independent necroptotic pathway. IAPs were shown to be overexpressed in AML cells and correlate with poor prognosis [117-119], so they are considered promising targets for therapeutic purposes. Smac mimetics have been artificially designed in recent years to antagonize IAP proteins [47, 48, 115, 120-122]. Thus, using Smac mimetics can induce necroptosis as an alternative option for AML cells that are refractory to apoptosis. [73]. Brumatti G et al. [123] found that AML cells are sensitive to clinical Smac mimetic birinapantinduced apoptosis. Blocking the activity of caspase- 8 by the clinical caspase inhibitor emricasan/IDN-6556 can augment the killing effect of birinapant by triggering necroptotic cell death. The researchers finally demonstrated the antileukemic efficacy and safety of the induction of necroptosis via a birinapant/emricasan combination in vivo, which should be clinically investigated as a therapeutic opportunity. Another type of Smac mimetic, BV6, can also elicit necroptosis depending on TNF- $\alpha$ and the activation of its downstream components of the necroptosis pathway, such as RIPK1, RIPK3 and MLKL, in AML cells, in which apoptosis is inhibited pharmacologically by the pan-caspase inhibitor zVAD-fmk or genetically by caspase-8 knockdown. Additionally, BV6 triggers necroptosis in apoptosisresistant patient-derived AML blasts [124]. Several studies have suggested that BV6 can act in concert with a series of commonly used clinical drugs in AML treatment, such as cytarabine, the demethylating agents azacitidine 
Table 1 Necroptosis-inducing anti-leukemia agents

\begin{tabular}{|c|c|c|c|c|}
\hline Disease & Agents & Targets & Mechanisms of necroptosis & Ref \\
\hline \multirow[t]{8}{*}{ AML } & Birinapant+Emricasan & CIAPs, caspase-8 & TNFR1 signaling; RIPK1/RIPK3/MLKL dependent & [123] \\
\hline & BV6+zVAD-fmk & cIAPs, pan-caspase & RIPK1/RIPK3/MLKL dependent; autocrine TNF-a & [124] \\
\hline & BV6+Cytarabine & clAPs, DNA synthesis & RIPK1/RIPK3/MLKL dependent; autocrine TNF-a & [125] \\
\hline & BV6+Azacitidine or Decitabine & CIAPs, DNA methylation & RIPK1/RIPK3/MLKL dependent; autocrine TNF-a & [126] \\
\hline & BV6+MS275 or SAHA & cIAPs, Histone deacetylase & RIPK1/RIPK3/MLKL dependent; autocrine TNF-a & [127] \\
\hline & HXR9 & HOX/PBX dimer & RIPK1 dependent & [133] \\
\hline & Diphtheria toxin GM-CSF & Protein synthesis & RIPK1 dependent & [137] \\
\hline & Erastin & Unknown & RIPK3 dependent; c-JNK and p38 dependent & [138] \\
\hline \multirow[t]{5}{*}{ ALL } & BV6+Dexamethasone & cIAPs, Glucocorticoid receptor & $\begin{array}{l}\text { RIPK1/RIPK3/MLKL activation; Bak activation and mitochondrial } \\
\text { perturbation }\end{array}$ & [143] \\
\hline & BV6, LCL161, Birinapant & CIAPS & $\begin{array}{l}\text { RIPK1/RIPK3/MLKL dependent; autocrine TNF-a; enhanced by } \\
\text { hyperosmotic stress }\end{array}$ & [145] \\
\hline & BV6 + Azacytidine & CIAPs, DNA methylation & RIPK1/RIPK3/MLKL-dependent; autocrine TNF-a & [145] \\
\hline & Obatoclax & $\mathrm{BCl}-2$ & Autophagy-dependent; mediated by RIPK1, CYLD & {$[149,151]$} \\
\hline & MG132, Bortezomib & Proteasome & $\begin{array}{l}\text { RIPK3/MLKL dependent; accumulation of polyubiquitinated } \\
\text { RIPK3 }\end{array}$ & [154] \\
\hline CLL & Ethacrynic acid & LEF1 & CYLD activation & {$[159,160]$} \\
\hline \multirow[t]{2}{*}{ CML } & LQFM018 & Unknown & $\begin{array}{l}\text { TNFR1 and CYLD upregulation; involvement of dopamine } \\
\text { D4 receptor }\end{array}$ & [165] \\
\hline & Pig7 & Lysosomal & MLKL activation; alteration of MMP and ROS levels & [167] \\
\hline
\end{tabular}

or decitabine and the histone deacetylase inhibitors MS275 or SAHA, to trigger necroptosis in apoptosis-resistant AML cells in a synergistic manner mediated by TNF $\alpha / R I P K 1 / R I P K 3 / M L K L$ activation [125-127]. Interestingly, the multitargeting kinase inhibitor sorafenib used for the treatment of AML [128] can limit BV6-induced necroptosis in apoptosis-resistant AML cells via inhibiting phosphorylation of MLKL, which has important implications for the application of sorafenib in treatment of AML [11]. Although admittedly still in early stages of development, some clinical studies with Smac mimetics have been performed in myeloid malignancies, including birinapant in AML (NCT01486784), myelodysplastic syndrome (NCT01828346, NCT02147873) and chronic myelomonocytic leukemia (NCT02147873). Additionally, there are/ have been some clinic trials using Smac mimetics (e.g., birinapant, LCL161 and AT-406) in lymphoma (NCT00993239, NCT01078649) and multiple myeloma (NCT03111992). Evidence obtained indicate that these Smac mimetics exert favorable antitumor activity in treatment resistance patients including leukemia and was well tolerated. Vomiting, nausea, diarrhea and other gastrointestinal symptoms were common side effects of these drugs but not severe. Neutropenia and cytokines releasing were also observed in some patients, but they are controllable [129-131]. The data above indicated that Smac mimetics might be a novel effective clinical agent in treating drug-resistance leukemia by triggering necroptosis, and thus need to be further studied.
In addition to the Smac mimetic-centered strategy, other methods or mechanisms have also been demonstrated to induce necroptosis and thus bypass apoptosis resistance in AML cells. Alharbi $\mathrm{R}$ et al. found that blocking the interaction of HOX family transcription factors, which play key roles in AML cell survival [132], with the cofactor PBX by a short, cell-penetrating peptide (HXR9) can induce necroptosis in AML-derived cell lines and primary AML cells from patients [133]. Additionally, this effect can be synergistically enhanced by the protein kinase C signaling inhibitor Ro31 [133]. Granulocyte-macrophage colony-stimulating factor receptors (GM-CSFR) are overexpressed in most AML cells [134], which are responsive to GM-CSF [135]. Thus, selectively targeting cells with increased levels of GM-CSF receptors may be a promising method for more effectively treating AML. Several studies have shown that a recombinant fusion protein diphtheria toxinGM-CSF (DT-GMCSF) exerts selective killing effects on AML cells by inducing apoptosis, while sparing normal hemopoietic cells $[134,136]$. Horita H's research showed that DT-GMCSF triggers necroptotic death in AML cells that are defective in apoptosis, suggesting that DT-GMCSF can activate multiple death pathways, including necroptosis and apoptosis [137]. In addition, the quinazolinone derivative erastin that exhibits synthetic lethality with expression of the RAS oncogene was recently shown to induce mixed types of cell death, including necroptosis, in AML cells. The erastin induced 
necroptosis is RIPK3 dependent manner and related to c-JUN N-terminal kinase (c-JNK) and p38 [138].

\section{Acute lymphoblastic leukemia}

Despite aggressive application of individualized chemotherapy, acute lymphoblastic leukemia (ALL) patients with high-risk, drug-refractory or relapsed disease still have a poor prognosis $[139,140]$. As in many tumors, general deregulation of cell death pathways and failure to undergo chemotherapy-induced apoptosis constitute a key mechanism for drug resistance and clonal escape in ALL $[141,142]$. This finding emphasizes the need to develop alternative strategies to induce other types of RCD, such as necroptosis, in ALL.

As mentioned above, Smac mimetic-based therapies are promising strategies to trigger necroptosis in apoptosis-resistant cells. The Smac mimetic BV6 and dexamethasone cooperate in the induction of necroptosis in ALL cells that are deficient in caspase-dependent apoptosis activation [143]. Furthermore. Rohde $\mathrm{K}$ et al. found that BV6/dexamethasone-triggered necroptosis relies on RIPK1/RIPK3/MLKL activation, followed by downstream Bak activation and mitochondrial perturbation (including ROS production and a drop in MMP), suggesting that mitochondrial dysfunction might serve as an amplification step in this process [143]. Using patient-derived xenograft models and CRISPR-based genome editing methodology, researchers demonstrated that another type of Smac mimetic, birinapant, can circumvent escape from apoptosis in drug-resistant and relapsed ALL by activating RIPK1/RIPK3/MLKLdependent necroptosis [144]. Similar to its effects in AML, the Smac mimetic BV6 can also cooperate with the demethylating agent azacytidine to induce necroptotic cell death in ALL cells that are resistant to apoptosis [145]. Interestingly, hyperosmotic stress can boost Smac mimetic (e.g., BV6, LCL161, birinapant)-induced necroptosis by complementary TNF secretion in ALL cells, thus indicating that physicochemical modulation of the tumor environment can be utilized to enhance treatment efficacy of Smac mimetic-based therapies for ALL [146].

Antiapoptotic $\mathrm{Bcl}-2$ protein family members (e.g., Mcl-1, Bcl- $\mathrm{X}_{\mathrm{L}}$ ) are highly expressed in ALL and are often associated with chemotherapy resistance [147, 148]. Based on these findings, the potential of the pan-Bcl-2 family small molecule inhibitor obatoclax for combination therapy in refractory ALL was studied. Bonapace L et al. demonstrated that a combination of obatoclax could resensitize multidrug-resistant childhood ALL cells to glucocorticoids through rapid activation of autophagydependent necroptosis [149]. MLL gene translocations, which occur in $75 \%$ of ALL in infants younger than 1 year old, are related to poor prognosis [150]. Additionally, the expression of Bcl-2 family members is often upregulated in MLL-translocation infant ALL cells [151]. Urtishak $\mathrm{K}$ et al.'s study described multiple death mechanisms, including necroptosis, of obatoclax in killing infant ALL primary cells with $M L L$ translocations that confer chemotherapy resistance [151]. Though the limited efficacy and significant toxicity of obatoclax in the recently clinic trials restrict its application in clinical therapy, obatoclax still has the potential as a cancer therapy when modified for less toxic side effects or when combined with other antileukemia agents [152]. Defects in the ubiquitin-proteasome system (UPS) can lead to various disorders, including tumorigenesis. Clinically targeting UPS has been proven to be an effective therapeutic approach in treating multiple cancers [153]. Moriwaki $\mathrm{K}$ et al. showed that treatment with the proteasome inhibitors MG132 and bortezomib can directly activate the necroptotic pathway in the ALL-derived cell line Jurkat, which is based on the RIPK3-MLKL interaction via RHIM domains [154].

\section{Chronic lymphoblastic leukemia}

Chronic lymphoblastic leukemia (CLL) refers to a hematological malignancy characterized by the clonal expansion and accumulation of small B lymphocytes that have a mature appearance [155]. Despite the substantial progress in pathobiology research and the development of effective treatment regimens, CLL remains incurable at present [156]. An impaired cell death program contributes to the accumulation of monoclonal B cells as well as chemotherapy resistance [157]. Recent studies have revealed that CLL cells have defects not only in the apoptosis program but also in the necroptosis pathway. Similar to other studies, researchers have observed the production of TNF $\alpha$ and degradation of cIAP1/2 in CLL cells treated with Smac mimetics. Unexpectedly, CLL cells are unable to form the ripoptosome complex and are killed by apoptosis or necroptosis, which may be associated with the aberrant upstream NF-kB regulation [158]. Li J's team also found that CLL cells failed to undergo necroptosis upon TNF- $\alpha /$ zVAD-fmk costimulation due to the strong downregulation of RIPK3 and CYLD [159]. Then, the researchers found that the high level of Lymphoid enhancer-binding factor 1 (LEF1), a downstream effector of $\mathrm{Wnt} / \beta$-catenin signaling, might act as a transcription repressor of CYLD and predict adverse prognosis (decreased TFS and OS) in CLL $[159,160]$. Inhibiting LEF1 by ethacrynic acid or gene knockdown can sensitize CLL cells to death receptor ligation-induced necroptosis, which may be a promising therapeutic strategy for CLL $[159,160]$. Venetoclax, a small and orally available molecule that specifically targets $\mathrm{Bcl}-2$, was recently approved by the United States Food and Drug Administration for the treatment of CLL. Venetoclax showed a manageable safety profile and induced substantial responses in patients with relapsed CLL, including those with poor prognostic 
features, and venetoclax represents the most likely future direction in targeted CLL therapy [161]. However, the relationship between necroptosis stimulation and the killing effects of venetoclax on CLL cells remains unclear and needs to be further investigated.

\section{Chronic myeloid leukemia}

The introduction of selective BCR-ABL tyrosine kinase inhibitors (TKIs) has significantly improved the prognosis of chronic myeloid leukemia (CML), mainly through inducing apoptotic cell death, but drug resistance still exists in some patients [162]. TKI-resistant CML cells are usually characterized by apoptosis resistance [163, 164] and thus require an alternative approach, such as necroptosis, to reactivate cell death in CML. Unfortunately, limited progress has been made in studying necroptosis in CML, probably due to its favorable prognosis. Here, we provide a brief review of this progress. A newly synthesized piperazine-containing compound, LQFM018, has been proven to promote necroptosis in the CML cell line K562, as shown by the cell membrane rupture, mitochondrial damage with MMP loss and ROS overproduction and upregulation of TNFR1 and CYLD, with no involvement of caspase- 3 and caspase- 8 activation. This process most likely involves the dopamine $\mathrm{D} 4$ receptor [165]. The p53-induced gene 7 (pig7), which localizes to the lysosomal membrane, is considered one of the key factors involved in p53-induced apoptosis [166]. Liu J and his colleagues' work has shown that overexpression of pig7 did not directly activate the caspase apoptotic pathway but decreased the lysosomal stability

and significantly sensitized the drug-resistant CML cell line K562/ADM (has low endogenous pig7 expression) to chemotherapeutic drugs through necroptosis

involving multiple cell death mechanisms. This cell death is associated with alteration of MMP and ROS levels, as well as MLKL activation [167]. In addition, homoharringtonine (HHT), a plant alkaloid that was recently approved by the FDA to treat patients with CML, is regarded as an efficient sensitizer for TRAIL-induced necroptosis in multiple human solid tumor cell lines [168]. Based on this finding, HHT/TRAIL combination therapy may be used to treat apoptosis-resistant CML, which needs to be further studied and confirmed.

\section{Conclusions}

Necroptosis has recently attracted attention as a form of RCD that can be triggered even under conditions of disabled apoptosis. Notably, activation of the RIP1/RIP3/ MLKL pathway was shown to be the main mechanism for necroptosis initiation and execution. Because apoptosis evasion represents a hallmark of human cancers, including leukemia, therapeutic induction of necroptosis may open new directions for treatment strategies in apoptosis-resistant leukemia. While a series of drugs and compounds have been shown to trigger necroptosis in leukemia cells, the precise molecular targets of most of these agents in promoting leukocyte necroptosis remain unclear. Additionally, evidence has shown that some components of the cell death pathway that mediate necroptosis are often scarce or even lacking, which prompted us to obtain a deeper understanding of the molecular signaling network that regulates necroptotic cell death. In conclusion, targeting necroptosis for the treatment of leukemia presents significant advantages over current strategies. However, a better understanding of the underlying molecular mechanisms of necroptosis is required before necroptosis can be used in clinical therapeutic interventions.

\section{Abbreviations}

ALL: Acute lymphoblastic leukemia; AML: Acute myeloid leukemia; APC: Antigen presenting cell; Bcl-2: B-cell lymphoma 2; CaMKII: $\mathrm{Ca}^{2}$ ${ }^{+}$-calmodulin-dependent protein kinase II; CASP8: Caspase-8; CFLIP: FLICElike inhibitory proteins; cFLIPL/S: Long/short type of CFLIP isoform; CIAP1/ 2: Cellular inhibitor of apoptosis protein 1, 2; c-JNK: c-JUN N-terminal kinase; CLL: Chronic lymphoblastic leukemia; CML: Chronic myeloid leukemia; CMV: Cytomegalovirus; CYLD: Cylindromatosis; DAl: DNA activator of interferon; DAMPs: Damage-associated molecular patterns; DDs: Death domains; DRs: Death receptors; dsDNA/RNA: Double strand DNA/RNA; DT-GMCSF: Diphtheria toxin GM-CSF; FADD: Fas-associated death domain protein; FASL: FAS ligand; GM-CSF: Granulocyte-macrophage colony-stimulating factor; GM-CSFR: GM-CSF receptor; HHT: Homoharringtonine; HMGB: High-mobility group protein; HSP: Heat-shock proteins; HSV-1: Herpes simplex virus 1; ICP6: Viral ribonucleotide reductase large subunit; IDO: Indoleamine 2,3-dioxygenase; IFNR: Interferon receptor; IFNs: Interferons; IKKa/B: IKB kinase a/B; IL-1: Interleukin-1; LEF1: Lymphoid enhancer-binding factor 1; LPS: Lipopolysaccharide; MAVS: Mitochondrial antiviral signaling protein; MK2: MAPK-activated protein kinase 2; MLKL: Mixed lineage kinase domain-like; MMP: Mitochondrial membrane potential; MPT: Mitochondrial permeability transition; Nec-1: Necrostatin-1; NEMO: Nuclear factor kappa B essential modulator; NF-kB: Nuclear factor kB; NLRs: NOD-like receptors;

NOD: Nucleotide-binding and oligomerization domain; NSA: Necrosulfonamide; PKR: Protein kinase R; RCD: Regulated cell death; RHIM: Respective homotypic interaction motif; RIG-I: Retinoic acid-inducible gene I; RIPK1, 3: Receptorinteracting protein kinase 1, 3; ROS: Reactive oxygen species; Smac: Second mitochondria-derived activator of caspases; TAB2, 3: Transforming growth factor $\beta$-activated kinase binding protein 2, 3; TAK1: Transforming growth factor $\beta$ activated kinase 1; TCR: T-cell receptor; TEM: Transmission electron microscopy; TICAM1: TIR domain-containing adapter molecule 1; TKIs: Tyrosine kinase inhibitors; TLR3, 4: Toll-like receptors 3, 4; TNFR1: TNF receptor 1; TNF-a: Tumor necrosis factor a; TRADD: TNF-a receptor associated death domain; TRAF2, 5: TNF-a receptor associate factor 2, 5; TRAIL: TNF-related apoptosis-inducing ligand; TRAILR: TRAIL receptor; TRIF: TIR-domain-containing adapter-inducing interferon- $\beta$; Ub: Ubiquitin; UPS: Ubiquitin-proteasome system; XIAP: X-linked inhibitor of apoptosis; ZBP1: Z-DNA binding protein 1

\section{Acknowledgments}

We thank the medical staffs from department of Hematology and department of pathology, the First Affiliated Hospital, College of Medicine, Zhejiang University.

\section{Funding}

We are grateful for financial support from the Funds of Science Technology Department of Zhejiang Province (No. 2016C33137), Funds of Health Department of Zhejiang Province (No. 2016KYB095 and No. 2019KY693), and Funds of Education Department of Zhejiang Province (No. Y201636714 and No. Y201635961).

Availability of data and materials Not applicable. 


\section{Authors' contributions}

XBH, FX, YL and WD drafted the manuscript; WBQ and XJY critically revised the manuscript. All authors have read and approved the final manuscript.

\section{Authors' information}

XBH, WBQ and XJY have a PhD in Medicine; FX and YL hold an MSc degree in Medicine. WBQ is a professor in the Department of Hematology. XJY is the director in the Department of Hematology. WD is the director of the Department of Pathology. XJY and WD are cocorrespondence authors.

\section{Ethics approval and consent to participate}

Not applicable.

\section{Consent for publication}

Not applicable.

\section{Competing interests}

The authors declare that they have no competing interests.

\section{Publisher's Note}

Springer Nature remains neutral with regard to jurisdictional claims in published maps and institutional affiliations.

\section{Author details}

${ }^{1}$ Department of Hematology, the First Affiliated Hospital, College of Medicine, Zhejiang University, 79\# Qingchun Road, Hangzhou 310003, China. ${ }^{2}$ Malignant Lymphoma Diagnosis and Therapy Center, the First Affiliated Hospital, College of Medicine, Zhejiang University, Hangzhou 310003, China. ${ }^{3}$ Department of Pathology, the First Affiliated Hospital, College of Medicine, Zhejiang University, 79\# Qingchun Road, Hangzhou 310003, China. ${ }^{4}$ Institute of Hematology, the First Hospital of Jiaxing, Jiaxing 314000, China.

Received: 22 October 2018 Accepted: 23 November 2018

Published online: 12 December 2018

\section{References}

1. Hanahan D, Weinberg RA. Hallmarks of cancer: the next generation. Cell. 2011;144(5):646-74.

2. Galluzzi L, Vitale I, Aaronson SA, Abrams JM, Adam D, Agostinis P, Alnemri ES, Altucci L, Amelio I, Andrews DW, Annicchiarico-Petruzzelli M, Antonov AV, Arama E, Baehrecke EH, Barlev NA, Bazan NG, Bernassola F, Bertrand MJM, Bianchi K, Blagosklonny MV, Blomgren K, Borner C, Boya P, Brenner C, Campanella M, Candi E, Carmona-Gutierrez D, Cecconi F, Chan FK, Chandel NS, Cheng EH, Chipuk JE, Cidlowski JA, Ciechanover A, Cohen GM, Conrad M, Cubillos-Ruiz JR, Czabotar PE, D'Angiolella V, Dawson TM, Dawson VL, De Laurenzi V, De Maria R, Debatin KM, DeBerardinis RJ, Deshmukh M, Di Daniele N, Di Virgilio F, Dixit VM, Dixon SJ, Duckett CS, Dynlacht BD, El-Deiry WS, Elrod JW, Fimia GM, Fulda S, García-Sáez AJ, Garg AD, Garrido C, Gavathiotis E, Golstein P, Gottlieb E, Green DR, Greene LA, Gronemeyer H, Gross A, Hajnoczky G, Hardwick JM, Harris IS, Hengartner MO, Hetz C, Ichijo $H$, Jäättelä $M$, Joseph $B$, Jost PJ, Juin PP, Kaiser WJ, Karin M, Kaufmann T, Kepp O, Kimchi A, Kitsis RN, Klionsky DJ, Knight RA, Kumar S, Lee SW, Lemasters JJ, Levine B, Linkermann A, Lipton SA, Lockshin RA, López-Otín C, Lowe SW, Luedde T, Lugli E, MacFarlane M, Madeo F, Malewicz M, Malorni W, Manic G, Marine JC, Martin SJ, Martinou JC, Medema JP, Mehlen P, Meier P, Melino S, Miao EA, Molkentin JD, Moll UM, Muñoz-Pinedo C, Nagata S, Nuñez G, Oberst A, Oren M, Overholtzer M, Pagano M, Panaretakis T, Pasparakis M, Penninger JM, Pereira DM, Pervaiz S, Peter ME, Piacentini M, Pinton P, Prehn JHM, Puthalakath H, Rabinovich GA, Rehm M, Rizzuto R, Rodrigues CMP, Rubinsztein DC, Rudel T, Ryan KM, Sayan E, Scorrano L, Shao F, Shi Y, Silke J, Simon HU, Sistigu A, Stockwell BR, Strasser A, Szabadkai G, Tait SWG, Tang D, Tavernarakis N, Thorburn A, Tsujimoto Y, Turk B, Vanden Berghe T, Vandenabeele P, Vander Heiden MG, Villunger A, Virgin HW, Vousden KH, Vucic D, Wagner EF, Walczak H, Wallach D, Wang Y, Wells JA, Wood W, Yuan J, Zakeri Z, Zhivotovsky B, Zitvogel L, Melino G, Kroemer G. Molecular mechanisms of cell death: recommendations of the Nomenclature Committee on Cell Death 2018. Cell Death Differ. 2018;25(3):486-541.

3. Montazami N, Aghapour M, Farajnia S, Baradaran B. New insights into the mechanisms of multidrug resistance in cancers. Cell Mol Biol (Noisy-le-grand). 2015;61(7):70-80
4. Galluzzi L, Vitale I, Abrams JM, Alnemri ES, Baehrecke EH, Blagosklonny MV, Dawson TM, Dawson VL, El-Deiry WS, Fulda S, Gottlieb E, Green DR, Hengartner MO, Kepp O, Knight RA, Kumar S, Lipton SA, Lu X, Madeo F, Malorni W, Mehlen P, Nuñez G, Peter ME, Piacentini M, Rubinsztein DC, Shi Y, Simon HU, Vandenabeele P, White E, Yuan J, Zhivotovsky B, Melino G, Kroemer G. Molecular definitions of cell death subroutines: recommendations of the Nomenclature Committee on Cell Death 2012. Cell Death Differ. 2012; 19(1):107-20.

5. Taylor RC, Cullen SP, Martin SJ. Apoptosis: controlled demolition at the cellular level. Nat Rev Mol Cell Biol. 2008;9(3):231-41.

6. Siegel RL, Miller KD, Jemal A. Cancer Statistics, 2017. CA Cancer J Clin. 2017; 67(1):7-30.

7. Degterev A, Huang Z, Boyce M, Li Y, Jagtap P, Mizushima N, Cuny GD, Mitchison TJ, Moskowitz MA, Yuan J. Chemical inhibitor of nonapoptotic cell death with therapeutic potential for ischemic brain injury. Nat Chem Biol. 2005; 1(2):112-9.

8. Pasparakis $M$, Vandenabeele $P$. Necroptosis and its role in inflammation. Nature. 2015;517(7534):311-20.

9. Ofengeim D, Yuan J. Regulation of RIP1 kinase signaling at the crossroads of inflammation and cell death. Nat Rev Mol Cell Biol. 2013;14(11):727-36.

10. Murphy JM, Czabotar PE, Hildebrand JM, Lucet IS, Zhang JG, Alvarez-Diaz S, Lewis R, Lalaoui N, Metcalf D, Webb Al, Young SN, Varghese LN, Tannahill GM, Hatchell EC, Majewski IJ, Okamoto T, Dobson RC, Hilton DJ, Babon JJ, Nicola NA, Strasser A, Silke J, Alexander WS. The pseudokinase MLKL mediates necroptosis via a molecular switch mechanism. Immunity. 2013; 39(3):443-53.

11. Feldmann F, Schenk B, Martens S, Vandenabeele P, Fulda S. Sorafenib inhibits therapeutic induction of necroptosis in acute leukemia cells. Oncotarget. 2017;8(40):68208-20.

12. Wu W, Liu P, Li J. Necroptosis: An emerging form of programmed cell death. Crit Rev Oncol Hematol. 2012;82(3):249-58.

13. Wyllie AH, Kerr JF, Currie AR. Cell death: the significance of apoptosis. Int Rev Cytol. 1980;68:251-306

14. Kerr JF, Wyllie AH, Currie AR. Apoptosis: A basic biological phenomenon with wide-ranging implications in tissue kinetics. Br J Cancer. 1972;26(4): 239-57.

15. Galluzzi L, Kepp O, Chan FK, Kroemer G. Necroptosis: Mechanisms and relevance to disease. Annu Rev Pathol. 2017:12:103-30.

16. Zhang $Q$, Raoof $M$, Chen $Y$, Sumi $Y$, Sursal T, Junger W, Brohi K, Itagaki $K$, Hauser CJ. Circulating mitochondrial DAMPs cause inflammatory responses to injury. Nature. 2010;464(7285):104-7.

17. Kaczmarek A, Vandenabeele P, Krysko DV. Necroptosis: the release of damage associated molecular patterns and its physiological relevance. Immunity. 2013;38(2):209-23.

18. Danial NN, Korsmeyer SJ. Cell death. Critical control points. Cell. 2004;116(2): 205-19.

19. Lalaoui N, Lindqvist LM, Sandow JJ, Ekert PG. The molecular relationships between apoptosis, autophagy and necroptosis. Semin Cell Dev Biol. 2015; 39:63-9.

20. Linkermann A, Green DR. Necroptosis. N Engl J Med. 2014;370(5):455-65

21. Mocarski ES, Guo H, Kaiser WJ. Necroptosis: The Trojan horse in cell autonomous antiviral host defense. Virology. 2015;479-480:160-6.

22. Chan FK, Shisler J, Bixby JG, Felices M, Zheng L, Appel M, Orenstein J, Moss $B$, Lenardo MJ. A role for tumor necrosis factor receptor-2 and receptorinteracting protein in programmed necrosis and antiviral responses. J Biol Chem. 2003;278(51):51613-21.

23. Vanlangenakker $N$, Vanden Berghe $T$, Vandenabeele P. Many stimuli pull the necrotic trigger, an overview. Cell Death Differ. 2012;19(1):75-86.

24. Christofferson DE, Yuan J. Necroptosis as an alternative form of programmed cell death. Curr Opin Cell Biol. 2010;22(2):263-8.

25. Guchelaar HJ, Vermes I, Koopmans RP, Reutelingsperger CP, Haanen C. Apoptosis- and necrosis-inducing potential of cladribine, cytarabine, cisplatin, and 5-fluorouracil in vitro: a quantitative pharmacodynamic model. Cancer Chemother Pharmacol. 1998:42(1):77-83.

26. Zong WX, Ditsworth D, Bauer DE, Wang ZQ, Thompson CB. Alkylating DNA damage stimulates a regulated form of necrotic cell death. Genes Dev. 2004;18(11):1272-82.

27. Long JS, Ryan KM. New frontiers in promoting tumour cell death: targeting apoptosis, necroptosis and autophagy. Oncogene. 2012;31(49):5045-60.

28. Goodall ML, Fitzwalter BE, Zahedi S, Wu M, Rodriquez D, Mulcahy-Levy JM, Green DR, Morgan M, Cramer SD, Thorburn A. The autophagy machinery 
controls cell death switching between apoptosis and necroptosis. Dev Cell. 2016:37(4):337-49.

29. Walczak H. Death receptor-ligand systems in cancer, cell death, and inflammation. Cold Spring Harb Perspect Biol. 2013;5(5):a008698.

30. Kaiser WJ, Sridharan H, Huang C, Mandal P, Upton JW, Gough PJ, Sehon CA, Marquis RW, Bertin J, Mocarski ES. Toll-like receptor 3-mediated necrosis via TRIF, RIP3, and MLKL. J Biol Chem. 2013;288(43):31268-79.

31. Thapa RJ, Nogusa S, Chen P, Maki JL, Lerro A, Andrake M, Rall GF, Degterev A, Balachandran S. Interferon-induced RIP1/RIP3-mediated necrosis requires PKR and is licensed by FADD and caspases. Proc Natl Acad Sci U S A. 2013; 110(33):E3109-18.

32. Upton JW, Kaiser WJ, Mocarski ES. DAI/ZBP1/DLM-1 complexes with RIP3 to mediate virus-induced programmed necrosis that is targeted by murine cytomegalovirus vIRA. Cell Host Microbe. 2012;11(3):290-7.

33. Tenev T, Bianchi K, Darding M, Broemer M, Langlais C, Wallberg F, Zachariou A, Lopez J, MacFarlane M, Cain K, Meier P. The Ripoptosome, a signaling platform that assembles in response to genotoxic stress and loss of IAPs. Mol Cell. 2011;43(3):432-48.

34. Vanden Berghe T, Linkermann A, Jouan-Lanhouet S, Walczak H, Vandenabeele P. Regulated necrosis: the expanding network of non-apoptotic cell death pathways. Nat Rev Mol Cell Biol. 2014;15(2):135-47.

35. Hitomi J, Christofferson DE, Ng A, Yao J, Degterev A, Xavier RJ, Yuan J. Identification of a molecular signaling network that regulates a cellular necrotic cell death pathway. Cell. 2008;135(7):1311-23.

36. Moreno-Gonzalez G, Vandenabeele P, Krysko DV. Necroptosis: A novel cell death modality and its potential relevance for critical care medicine. Am J Respir Crit Care Med. 2016;194(4):415-28.

37. Grootjans S, Vanden Berghe T, Vandenabeele P. Initiation and execution mechanisms of necroptosis: An overview. Cell Death Differ. 2017;24(7):1184-95.

38. Tummers B, Green DR. Caspase-8: Regulating life and death. Immunol Rev. 2017;277(1):76-89.

39. Liu X, Shi F, Li Y, Yu X, Peng S, Li W, Luo X, Cao Y. Post-translational modifications as key regulators of TNF-induced necroptosis. Cell Death Dis. 2016;7(7):e2293.

40. Vandenabeele P, Galluzzi L, Vanden Berghe T, Kroemer G. Molecular mechanisms of necroptosis: an ordered cellular explosion. Nat Rev Mol Cell Biol. 2010;11(10):700-14.

41. Oberst A. Death in the fast lane: what's next for necroptosis? FEBS J. 2016; 283(14):2616-25

42. Silke J. The regulation of TNF signalling: what a tangled web we weave. Curr Opin Immunol. 2011;23(5):620-6.

43. Li H, Kobayashi M, Blonska M, You Y, Lin X. Ubiquitination of RIP is required for tumor necrosis factor alpha-induced NF-kappaB activation. J Biol Chem. 2006;281(19):13636-43.

44. Ea CK, Deng L, Xia ZP, Pineda G, Chen ZJ. Activation of IKK by TNFa Requires Site-Specific Ubiquitination of RIP1 and Polyubiquitin Binding by NEMO. Mol Cell. 2006:22(2):245-57.

45. Vanden Berghe T, Kaiser WJ, Bertrand MJ, Vandenabeele P. Molecular crosstalk between apoptosis, necroptosis, and survival signaling. Mol Cell Oncol. 2015;2(4):e975093.

46. Micheau O, Lens S, Gaide O, Alevizopoulos K, Tschopp J. NF-kappaB signals induce the expression of C-FLIP. Mol Cell Biol. 2001;21(16):5299-305.

47. Vince JE, Wong WW, Khan N, Feltham R, Chau D, Ahmed AU, Benetatos CA, Chunduru SK, Condon SM, McKinlay M, Brink R, Leverkus M, Tergaonkar V, Schneider P, Callus BA, Koentgen F, Vaux DL, Silke J. IAP antagonists target CIAP1 to induce TNFalpha-dependent apoptosis. Cell. 2007;131(4):682-93.

48. Li L, Thomas RM, Suzuki H, De Brabander JK, Wang X, Harran PG. A smal molecule Smac mimic potentiates TRAIL- and TNFalpha-mediated cell death. Science. 2004;305(5689):1471-4.

49. Tsuchiya Y, Nakabayashi O, Nakano H. FLIP the Switch: Regulation of Apoptosis and Necroptosis by cFLIP. Int J Mol Sci. 2015;16(12):30321-41.

50. Hughes MA, Harper N, Butterworth M, Cain K, Cohen GM, MacFarlane M. Reconstitution of the death-inducing signaling complex reveals a substrate switch that determines CD95-mediated death or sunvival. Mol Cell. 2009:35(3):265-79.

51. Dickens LS, Boyd RS, Jukes-Jones R, Hughes MA, Robinson GL, Fairall L, Schwabe JW, Cain K, Macfarlane M. A death effector domain chain DISC model reveals a crucial role for caspase-8 chain assembly in mediating apoptotic cell death. Mol Cell. 2012;47(2):291-305.

52. Feng S, Yang Y, Mei Y, Ma L, Zhu DE, Hoti N, Castanares M, Wu M. Cleavage of RIP3 inactivates its caspase-independent apoptosis pathway by removal of kinase domain. Cell Signal. 2007;19(10):2056-67.
53. Lin Y, Devin A, Rodriguez Y, Liu ZG. Cleavage of the death domain kinase RIP by Caspase-8 prompts TNF-induced apoptosis. Genes Dev. 1999;13(19): $2514-26$.

54. Feoktistova M, Geserick P, Kellert B, Dimitrova DP, Langlais C, Hupe M, Cain K, MacFarlane M, Häcker G, Leverkus M. cIAPs Block Ripoptosome Formation, a RIP1/Caspase-8 Containing Intracellular Cell Death Complex Differentially Regulated by cFLIP Isoforms. Mol Cell. 2011;43(3):449-63.

55. Dondelinger $Y$, Jouan-Lanhouet $S$, Divert $T$, Theatre E, Bertin J, Gough PJ, Giansanti P, Heck AJ, Dejardin E, Vandenabeele P, Bertrand MJ. NF-KBIndependent Role of IKKa/IKK $\beta$ in Preventing RIPK1 Kinase-Dependent Apoptotic and Necroptotic Cell Death during TNF Signaling. Mol Cell. 2015; 60(1):63-76.

56. Jaco I, Annibaldi A, Lalaoui N, Wilson R, Tenev T, Laurien L, Kim C, Jamal K, Wicky John S, Liccardi G, Chau D, Murphy JM, Brumatti G, Feltham R, Pasparakis M, Silke J, Meier P. MK2 Phosphorylates RIPK1 to Prevent TNF-Induced Cell Death. Mol Cell. 2017;66(5):698-710.

57. Dondelinger Y, Delanghe T, Rojas-Rivera D, Priem D, Delvaeye T, Bruggeman I, Van Herreweghe F, Vandenabeele P, Bertrand MJM. MK2 phosphonylation of RIPK1 regulates TNF-mediated cell death. Nat Cell Biol. 2017;19(10):1237-47.

58. Menon MB, Gropengießer J, Fischer J, Novikova L, Deuretzbacher A, Lafera J, Schimmeck H, Czymmeck N, Ronkina N, Kotlyarov A, Aepfelbacher M, Gaestel M, Ruckdeschel K. p38 ${ }^{\mathrm{MAPK}} / \mathrm{MK}$ 2-dependent phosphorylation controls cytotoxic RIPK1 signalling in inflammation and infection. Nat Cell Biol. 2017;19(10):1248-59.

59. Geserick P, Hupe M, Moulin M, Wong WW, Feoktistova M, Kellert B, Gollnick H, Silke J, Leverkus M. Cellular IAPs inhibit a cryptic CD95-induced cell death by limiting RIP1 kinase recruitment. J Cell Biol. 2009;187(7):1037-54.

60. Varfolomeev E, Blankenship JW, Wayson SM, Fedorova AV, Kayagaki N, Garg P, Zobel K, Dynek JN, Elliott LO, Wallweber HJ, Flygare JA, Fairbrother WJ, Deshayes K, Dixit VM, Vucic D. IAP antagonists induce autoubiquitination of C-IAPs, NF-kappaB activation, and TNFalpha-dependent apoptosis. Cell. 2007; 131(4):669-81.

61. Yang QH, Du C. Smac/DIABLO selectively reduces the levels of C-IAP1 and C-IAP2 but not that of XIAP and livin in HeLa cells. J Biol Chem. 2004; 279(17):16963-70

62. Moquin DM, McQuade T, Chan FK. CYLD Deubiquitinates RIP1 in the TNFaInduced Necrosome to Facilitate Kinase Activation and Programmed Necrosis. PLoS One. 2013;8(10):e76841.

63. Wright A, Reiley WW, Chang M, Jin W, Lee AJ, Zhang M, Sun SC. Regulation of Early Wave of Germ Cell Apoptosis and Spermatogenesis by Deubiquitinating Enzyme CYLD. Dev Cell. 2007;13(5):705-16.

64. Moulin M, Anderton H, Voss AK, Thomas T, Wong WW, Bankovacki A, Feltham R, Chau D, Cook WD, Silke J, Vaux DL. IAPs limit activation of RIP kinases by TNF receptor 1 during development. EMBO J. 2012;31(7):1679-91.

65. Li J, McQuade T, Siemer AB, Napetschnig J, Moriwaki K, Hsiao YS, Damko E, Moquin D, Walz T, McDermott A, Chan FK, Wu H. The RIP1/RIP3 necrosome forms a functional amyloid signaling complex required for programmed necrosis. Cell. 2012;150(2):339-50

66. Dondelinger Y, Aquileta MA, Goossens V, Dubuisson C, Grootjans S, Dejardin E, Vandenabeele P, Bertrand MJ. RIPK3 contributes to TNFR1-mediated RIPK1 kinase-dependent apoptosis in conditions of CIAP1/2 depletion or TAK1 kinase inhibition. Cell Death Differ. 2013;20(10):1381-92.

67. Wang L, Du F, Wang X. TNF-alpha induces two distinct caspase-8 activation pathways. Cell. 2008;133(4):693-703.

68. McQuade T, Cho Y, Chan FK. Positive and negative phosphorylation regulates RIP1- and RIP3-induced programmed necrosis. Biochem J. 2013;456(3):409-15.

69. Legarda-Addison D, Hase H, O'Donnell MA, Ting AT. NEMO/IKKgamma regulates an early NF-kappaB-independent cell-death checkpoint during TNF signaling. Cell Death Differ. 2009;16(9):1279-88.

70. Murphy JM, Silke J. Ars Moriendi; the art of dying well - new insights into the molecular pathways of necroptotic cell death. EMBO Rep. 2014;15(2):155-64.

71. Cho YS, Challa S, Moquin D, Genga R, Ray TD, Guildford M, Chan FK. Phosphorylation driven assembly of the RIP1-RIP3 complex regulates programmed necrosis and virus-induced inflammation. Cell. 2009;137(6): 1112-23.

72. Sun L, Wang H, Wang Z, He S, Chen S, Liao D, Wang L, Yan J, Liu W, Lei X, Wang $X$. Mixed lineage kinase domain-like protein mediates necrosis signaling downstream of RIP3 kinase. Cell. 2012;148(1-2):213-27.

73. Laukens B, Jennewein C, Schenk B, Vanlangenakker N, Schier A, Cristofanon S, Zobel K, Deshayes K, Vucic D, Jeremias I, Bertrand MJ, Vandenabeele P, 
Fulda S. Smac mimetic bypasses apoptosis resistance in FADD- or caspase8-deficient cells by priming for tumor necrosis factor a-induced necroptosis. Neoplasia. 2011;13(10):971-9.

74. Philchenkov A, Miura K. The IAP protein family, SMAC mimetics, and cancer treatment. Crit Rev Oncog. 2016;21(3-4):185-202.

75. Zhang Y, Su SS, Zhao S, Yang Z, Zhong CQ, Chen X, Cai Q, Yang ZH, Huang D, Wu R, Han J. RIP1 autophosphorylation is promoted by mitochondrial ROS and is essential for RIP3 recruitment into necrosome. Nat Commun. 2017:8:14329.

76. He S, Liang $Y$, Shao F, Wang $X$. Toll-like receptors activates programmed necrosis in macrophages through a receptor-interacting kinase-3 mediated pathway. Proc Natl Acad Sci U S A. 2011;108(50):20054-9.

77. Rebsamen M, Heinz LX, Meylan E, Michallet MC, Schroder K, Hofmann K, Vazquez J, Benedict CA, Tschopp J. DAI/ZBP1 recruits RIP1 and RIP3 through RIP homotypic interaction motifs to activate NF-kappaB. EMBO Rep. 2009; 10(8):916-22.

78. Vanden Berghe T, Kaiser WJ. RIPK1 prevents aberrant ZBP1-initiated necroptosis. Oncotarget. 2017;8(1):1-2.

79. Wang X, Li Y, Liu S, Yu X, Li L, Shi C, He W, Li J, Xu L, Hu Z, Yu L, Yang Z, Chen Q, Ge L, Zhang Z, Zhou B, Jiang X, Chen S, He S. Direct activation of RIP3/MLKL-dependent necrosis by herpes simplex virus 1 (HSV-1) protein ICP6 triggers host antiviral defense. Proc Natl Acad Sci U S A. 2014;111(43): 15438-43.

80. Upton JW, Kaiser WJ, Mocarski ES. Virus inhibition of RIP3-dependent necrosis. Cell Host Microbe. 2010;7(4):302-13.

81. Huang Z, Wu SQ, Liang Y, Zhou X, Chen W, Li L, Wu J, Zhuang Q, Chen C, Li J, Zhong CQ, Xia W, Zhou R, Zheng C, Han J. RIP1/RIP3 binding to HSV-1 ICP6 initiates necroptosis to restrict virus propagation in mice. Cell Host Microbe. 2015;17(2):229-42

82. Newton K, Wickliffe KE, Maltzman A, Dugger DL, Strasser A, Pham VC, Lill JR, Roose-Girma M, Warming S, Solon M, Ngu H, Webster JD, Dixit VM. RIPK1 inhibits ZBP1-driven necroptosis during development. Nature. 2016; 540(7631):129-33.

83. Lin J, Kumari S, Kim C, Van TM, Wachsmuth L, Polykratis A, Pasparakis M. RIPK1 counteracts ZBP1-mediated necroptosis to inhibit inflammation. Nature. 2016;540(7631):124-8.

84. Wu J, Huang Z, Ren J, Zhang Z, He P, Li Y, Ma J, Chen W, Zhang Y, Zhou X, Yang Z, Wu SQ, Chen L, Han J. MLKL knockout mice demonstrate the indispensable role of MLKL in necroptosis. Cell Res. 2013;23(8):994-1006.

85. Xie T, Peng W, Yan C, Wu J, Gong X, Shi Y. Structural insights into RIP3mediated necroptotic signaling. Cell Rep. 2013;5(1):70-8.

86. Hildebrand JM, Tanzer MC, Lucet IS, Young SN, Spall SK, Sharma P, Pierotti C, Garnier JM, Dobson RC, Webb Al, Tripaydonis A, Babon JJ, Mulcair MD, Scanlon MJ, Alexander WS, Wilks AF, Czabotar PE, Lessene G, Murphy JM, Silke J. Activation of the pseudokinase MLKL unleashes the four-helix bundle domain to induce membrane localization and necroptotic cell death. Proc Natl Acad Sci U S A. 2014;111(42):15072-7.

87. Cai Z, Jitkaew S, Zhao J, Chiang HC, Choksi S, Liu J, Ward Y, Wu LG, Liu ZG Plasma membrane translocation of trimerized MLKL protein is required for TNF-induced necroptosis. Nat Cell Biol. 2014;16(1):55-65.

88. Dondelinger $Y$, Declercq W, Montessuit S, Roelandt R, Goncalves A, Bruggeman I, Hulpiau P, Weber K, Sehon CA, Marquis RW, Bertin J, Gough PJ, Savvides S, Martinou JC, Bertrand MJ, Vandenabeele P. MLKL compromises plasma membrane integrity by binding to phosphatidylinositol phosphates. Cell Rep. 2014;7(4):971-81.

89. Wang H, Sun L, Su L, Rizo J, Liu L, Wang LF, Wang FS, Wang X. Mixed lineage kinase domain-like protein MLKL causes necrotic membrane disruption upon phosphorylation by RIP3. Mol Cell. 2014;54(1):133-46.

90. Melo MN, Ferre R, Castanho MA. Antimicrobial peptides: linking partition, activity and high membrane-bound concentrations. Nat Rev Microbiol. 2009; $7(3): 245-50$.

91. Chen W, Zhou Z, Li L, Zhong CQ, Zheng X, Wu X, Zhang Y, Ma H, Huang D, Li W, Xia Z, Han J. Diverse sequence determinants control human and mouse receptor interacting protein 3 (RIP3) and mixed lineage kinase domain-like (MLKL) interaction in necroptotic signaling. J Biol Chem. 2013;288(23):16247-61.

92. Huang $D$, Zheng $X$, Wang ZA, Chen $X$, He WT, Zhang $Y, X u J G$, Zhao H, Shi W, Wang $X$, Zhu Y, Han J. MLKL channel in necroptosis is octamer formed by tetramers in a dyadic process. Mol Cell Biol. 2017;37(5):e00497-16.

93. Chen X, Li W, Ren J, Huang D, He WT, Song Y, Yang C, Li W, Zheng X, Chen $P$, Han J. Translocation of mixed lineage kinase domain-like protein to plasma membrane leads to necrotic cell death. Cell Res. 2014;24(1):105-21.
94. Ros U, Peña-Blanco A, Hänggi K, Kunzendorf U, Krautwald S, Wong WW, García-Sáez AJ. Necroptosis execution is mediated by plasma membrane nanopores independent of calcium. Cell Rep. 2017;19(1):175-87.

95. Zhang T, Zhang Y, Cui M, Jin L, Wang Y, Lv F, Liu Y, Zheng W, Shang H, Zhang J, Zhang M, Wu H, Guo J, Zhang X, Hu X, Cao CM, Xiao RP. CaMKII is a RIP3 substrate mediating ischemia- and oxidative stress-induced myocardial necroptosis. Nat Med. 2016;22(2):175-82.

96. Schenk B, Fulda S. Reactive oxygen species regulate Smac mimetic/TNFalphainduced necroptotic signaling and cell death. Oncogene. 2015;34(47):5796-806.

97. Gupta K, Madan E, Sayyid M, Arias-Pulido H, Moreno E, Kuppusamy P, Gogna R. Oxygen regulates molecular mechanisms of cancer progression and metastasis. Cancer Metastasis Rev. 2014;33(1):183-215.

98. Canli O, Alankus YB, Grootjans S, Vegi N, Hultner L, Hoppe PS, Schroeder T, Vandenabeele P, Bornkamm GW, Greten FR. Glutathione peroxidase 4 prevents necroptosis in mouse erythroid precursors. Blood. 2016;127(1):139-48.

99. Krysko DV, Garg AD, Kaczmarek A, Krysko O, Agostinis P, Vandenabeele P. Immunogenic cell death and DAMPs in cancer therapy. Nat Rev Cancer. 2012;12(12):860-75.

100. Srikrishna G, Freeze HH. Endogenous damage-associated molecular pattern molecules at the crossroads of inflammation and cancer. Neoplasia. 2009; 11(7):615-28.

101. Dhuriya YK, Sharma D. Necroptosis: a regulated inflammatory mode of cell death. J Neuroinflammation. 2018;15(1):199.

102. Duprez L, Takahashi N, Van Hauwermeiren F, Vandendriessche B, Goossens V, Vanden Berghe T, Declerca W, Libert C, Cauwels A, Vandenabeele P. RIP kinase-dependent necrosis drives lethal systemic inflammatory response syndrome. Immunity. 2011;35(6):908-18.

103. Huang C, Luo Y, Zhao J, Yang F, Zhao H, Fan W, Ge P. Shikonin Kills Glioma Cells through Necroptosis Mediated by RIP-1. PLoS One. 2013;8(6):e66326.

104. Iannielli A, Bido S, Folladori L, Segnali A, Cancellieri C, Maresca A, Massimino L, Rubio A, Morabito G, Caporali L, Tagliavini F, Musumeci O, Gregato G, Bezard E, Carelli V, Tiranti V, Broccoli V. Pharmacological Inhibition of Necroptosis Protects from Dopaminergic Neuronal Cell Death in Parkinson's Disease Models. Cell Rep. 2018;22(8):2066-79.

105. Geng J, Ito Y, Shi L, Amin P, Chu J, Ouchida AT, Mookhtiar AK, Zhao H, Xu D, Shan B, Najafov A, Gao G, Akira S, Yuan J. Regulation of RIPK1 activation by TAK1-mediated phosphorylation dictates apoptosis and necroptosis. Nat Commun. 2017:8(1):359.

106. Jiao D, Cai Z, Choksi S, Ma D, Choe M, Kwon HJ, Baik JY, Rowan BG, Liu C, Liu ZG. Necroptosis of tumor cells leads to tumor necrosis and promotes tumor metastasis. Cell Res. 2018;28(8):868-70.

107. Takahashi N, Duprez L, Grootjans S, Cauwels A, Nerinckx W, DuHadaway JB, Goossens V, Roelandt R, Van Hauwermeiren F, Libert C, Declercq W, Callewaert N, Prendergast GC, Degterev A, Yuan J, Vandenabeele P. Necrostatin-1 analogues: critical issues on the specificity, activity and in vivo use in experimental disease models. Cell Death Dis. 2012;3:e437.

108. Harris PA, Berger SB, Jeong JU, Nagilla R, Bandyopadhyay D, Campobasso N, Capriotti CA, Cox JA, Dare L, Dong X, Eidam PM, Finger JN, Hoffman SJ, Kang J, Kasparcova V, King BW, Lehr R, Lan Y, Leister LK, Lich JD, TT MD, Miller NA, Ouellette MT, Pao CS, Rahman A, Reilly MA, Rendina AR, Rivera EJ, Schaeffer MC, Sehon CA, Singhaus RR, Sun HH, Swift BA, Totoritis RD, Vossenkämper A, Ward P, Wisnoski DD, Zhang D, Marquis RW, Gough PJ, Bertin J. Discovery of a First-in-Class Receptor Interacting Protein 1 (RIP1) Kinase Specific Clinical Candidate (GSK2982772) for the Treatment of Inflammatory Diseases. J Med Chem. 2017;60(4):1247-61.

109. Mandal P, Berger SB, Pillay S, Moriwaki K, Huang C, Guo H, Lich JD, Finger J, Kasparcova V, Votta B, Ouellette M, King BW, Wisnoski D, Lakdawala AS, DeMartino MP, Casillas LN, Haile PA, Sehon CA, Marquis RW, Upton J, DaleyBauer LP, Roback L, Ramia N, Dovey CM, Carette JE, Chan FK, Bertin J, Gough PJ, Mocarski ES, Kaiser WJ. RIP3 induces apoptosis independent of pronecrotic kinase activity. Mol Cell. 2014;56(4):481-95.

110. Li JX, Feng JM, Wang Y, Li XH, Chen XX, Su Y, Shen YY, Chen Y, Xiong B, Yang CH, Ding J, Miao ZH. The B-Raf(V600E) inhibitor dabrafenib selectively inhibits RIP3 and alleviates acetaminophen-induced liver injury. Cell Death Dis. 2014;5:e1278.

111. Fauster A, Rebsamen M, Huber KV, Bigenzahn JW, Stukalov A, Lardeau CH, Scorzoni S, Bruckner M, Gridling M, Parapatics K, Colinge J, Bennett KL, Kubicek S, Krautwald S, Linkermann A, Superti-Furga G. A cellular screen identifies ponatinib and pazopanib as inhibitors of necroptosis. Cell Death Dis. 2015;6:e1767.

112. Fulda S. Therapeutic exploitation of necroptosis for cancer therapy. Semin Cell Dev Biol. 2014;35:51-6. 
113. Estey E, Döhner H. Acute myeloid leukaemia. Lancet. 2006;368(9550):1894-907.

114. Fulda S, Debatin KM. Extrinsic versus intrinsic apoptosis pathways in anticancer chemotherapy. Oncogene. 2006;25(34):4798-811.

115. Fulda $S$, Vucic D. Targeting IAP proteins for therapeutic intervention in cancer. Nat Rev Drug Discov. 2012;11(2):109-24.

116. Eckelman BP, Salvesen GS, Scott FL. Human inhibitor of apoptosis proteins: why XIAP is the black sheep of the family. EMBO Rep. 2006;7(10):988-94.

117. Tamm I, Kornblau SM, Segall H, Krajewski S, Welsh K, Kitada S, Scudiero DA, Tudor G, Qui YH, Monks A, Andreeff M, Reed JC. Expression and prognostic significance of IAP-family genes in human cancers and myeloid leukemias. Clin Cancer Res. 2000;6(5):1796-803.

118. Bullinger L, Rücker FG, Kurz S, Du J, Scholl C, Sander S, Corbacioglu A, Lottaz C, Krauter J, Fröhling S, Ganser A, Schlenk RF, Döhner K, Pollack JR, Döhner H. Gene-expression profiling identifies distinct subclasses of core binding factor acute myeloid leukemia. Blood. 2007;110(4):1291-300.

119. Lück SC, Russ AC, Botzenhardt U, Paschka P, Schlenk RF, Döhner H, Fulda S, Döhner K, Bullinger L. Deregulated apoptosis signaling in core-binding factor leukemia differentiates clinically relevant, molecular marker-independent subgroups. Leukemia. 2011;25(11):1728-38.

120. Gaither A, Porter D, Yao Y, Borawski J, Yang G, Donovan J, Sage D, Slisz J, Tran M, Straub C, Ramsey T, lourgenko V, Huang A, Chen Y, Schlegel R, Labow M, Fawell S, Sellers WR, Zawel L. A Smac mimetic rescue screen reveals roles for inhibitor of apoptosis proteins in tumor necrosis factor-a signaling. Cancer Res. 2007;67(24):11493-8.

121. Hird AW, Aquila BM, Hennessy EJ, Vasbinder MM, Yang B. Small molecule inhibitor of apoptosis proteins antagonists: a patent review. Expert Opin Ther Pat. 2015;25(7):755-74.

122. Condon SM, Mitsuuchi Y, Deng Y, LaPorte MG, Rippin SR, Haimowitz T, Alexander MD, Kumar PT, Hendi MS, Lee YH, Benetatos CA, Yu G, Kapoor GS, Neiman E, Seipel ME, Burns JM, Graham MA, McKinlay MA, Li X, Wang J, Shi Y, Feltham R, Bettjeman B, Cumming MH, Vince JE, Khan N, Silke J, Day $\mathrm{CL}$, Chunduru SK. Birinapant, a smac-mimetic with improved tolerability for the treatment of solid tumors and hematological malignancies. J Med Chem. 2014:57(9):3666-77.

123. Brumatti G, Ma C, Lalaoui N, Nguyen NY, Navarro M, Tanzer MC, Richmond J, Ghisi M, Salmon JM, Silke N, Pomilio G, Glaser SP, de Valle E, Gugasyan R, Gurthridge MA, Condon SM, Johnstone RW, Lock R, Salvesen G, Wei A, Vaux $D L$, Ekert PG, Silke J. The caspase-8 inhibitor emricasan combines with the SMAC mimetic birinapant to induce necroptosis and treat acute myeloid leukemia. Sci Transl Med. 2016;8(339):339ra69.

124. Safferthal C, Rohde K, Fulda S. Therapeutic targeting of necroptosis by Smac mimetic bypasses apoptosis resistance in acute myeloid leukemia cells. Oncogene. 2017;36(11):1487-502.

125. Chromik J, Safferthal C, Serve H, Fulda S. Smac mimetic primes apoptosisresistant acute myeloid leukaemia cells for cytarabine-induced cell death by triggering necroptosis. Cancer Lett. 2014;344(1):101-9.

126. Steinhart L, Belz K, Fulda S. Smac mimetic and demethylating agents synergistically trigger cell death in acute myeloid leukemia cells and overcome apoptosis resistance by inducing necroptosis. Cell Death Dis. 2013;4:e802.

127. Steinwascher S, Nugues AL, Schoeneberger H, Fulda S. Identification of a novel synergistic induction of cell death by Smac mimetic and HDAC inhibitors in acute myeloid leukemia cells. Cancer Lett. 2015;366(1):32-43.

128. Daver N, Konopleva M. Sorafenib and novel multikinase inhibitors in AML. Lancet Oncol. 2015;16(16):1582-3.

129. DiPersio JF, Erba HP, Larson RA, Luger SM, Tallman MS, Brill JM, Vuagniaux G, Rouits E, Sorensen JM, Zanna C. Oral Debio1143 (AT406), an antagonist of inhibitor of apoptosis proteins, combined with daunorubicin and cytarabine in patients with poor-risk acute myeloid leukemia--results of a phase I doseescalation study. Clin Lymphoma Myeloma Leuk. 2015;15(7):443-9.

130. Amaravadi RK, Schilder RJ, Martin LP, Levin M, Graham MA, Weng DE, Adjei AA. A Phase I Study of the SMAC-Mimetic Birinapant in Adults with Refractory Solid Tumors or Lymphoma. Mol Cancer Ther. 2015;14(11):2569-75.

131. Infante JR, Dees EC, Olszanski AJ, Dhuria SV, Sen S, Cameron S, Cohen RB. Phase I dose-escalation study of LCL161, an oral inhibitor of apoptosis proteins inhibitor, in patients with advanced solid tumors. J Clin Oncol. 2014;32(28):3103-10.

132. Alharbi RA, Pettengell R, Pandha HS, Morgan R. The role of HOX genes in normal hematopoiesis and acute leukemia. Leukemia. 2013;27(5):1000-8.

133. Alharbi RA, Pandha HS, Simpson GR, Pettengell R, Poterlowicz K, Thompson A, Harrington K, El-Tanani M, Morgan R. Inhibition of HOX/PBX dimer formation leads to necroptosis in acute myeloid leukemia cells. Oncotarget. 2017:8(52): 89566-79.
134. Hogge DE, Willman CL, Kreitman RJ, Berger M, Hall PD, Kopecky KJ, McLain C, Tagge EP, Eaves CJ, Frankel AE. Malignant progenitors from patients with acute myelogenous leukemia are sensitive to a diphtheria toxin-granulocytemacrophage colony-stimulating factor fusion protein. Blood. 1998;92(2):589-95.

135. Budel LM, Touw IP, Delwel R, Clark SC, Löwenberg B. Interleukin-3 and granulocyte-monocyte colony-stimulating factor receptors on human acute myelocytic leukemia cells and relationship to the proliferative response. Blood. 1989;74(2):565-71.

136. Terpstra W, Rozemuller H, Breems DA, Rombouts EJ, Prins A, FitzGerald DJ, Kreitman RJ, Wielenga JJ, Ploemacher RE, Löwenberg B, Hagenbeek A, Martens AC. Diphtheria toxin fused to granulocyte-macrophage colonystimulating factor eliminates acute myeloid leukemia cells with the potential to initiate leukemia in immunodeficient mice, but spares normal hemopoietic stem cells. Blood. 1997;90(9):3735-42

137. Horita H, Frankel AE, Thorburn A. Acute myeloid leukemia-targeted toxin activates both apoptotic and necroptotic death mechanisms. PLoS One. 2008;3(12):e3909.

138. Yu Y, Xie Y, Cao L, Yang L, Yang M, Lotze MT, Zeh HJ, Kang R, Tang D. The ferroptosis inducer erastin enhances sensitivity of acute myeloid leukemia cells to chemotherapeutic agents. Mol Cell Oncol. 2015;2(4):e1054549.

139. Locatelli F, Schrappe M, Bernardo ME, Rutella S. Rutella, How I treat relapsed childhood acute lymphoblastic leukemia. Blood. 2012;120(14):2807-16.

140. Curran E, Stock W. How I treat acute lymphoblastic leukemia in older adolescents and young adults. Blood. 2015;125(24):3702-10.

141. Fulda S. Tumor resistance to apoptosis. Int J Cancer. 2009;124(3):511-5.

142. Fulda $\mathrm{S}$. Therapeutic opportunities for counteracting apoptosis resistance in childhood leukaemia. Br J Haematol. 2009;145(4):441-54.

143. Rohde K, Kleinesudeik L, Roesler S, Löwe O, Heidler J, Schröder K, Wittig I, Dröse S, Fulda S. A Bak-dependent mitochondrial amplification step contributes to Smac mimetic/glucocorticoid-induced necroptosis. Cell Death Differ. 2017;24(1):83-97.

144. McComb S, Aguadé-Gorgorió J, Harder L, Marovca B, Cario G, Eckert C, Schrappe M, Stanulla M, von Stackelberg A, Bourquin JP, Bornhauser BC. Activation of concurrent apoptosis and necroptosis by SMAC mimetics for the treatment of refractory and relapsed ALL. Sci Transl Med. 2016;8(339):339ra70.

145. Gerges S, Rohde K, Fulda S. Cotreatment with Smac mimetics and demethylating agents induces both apoptotic and necroptotic cell death pathways in acute lymphoblastic leukemia cells. Cancer Lett. 2016;375(1):127-32.

146. Bittner S, Knoll G, Ehrenschwender M. Hyperosmotic stress enhances cytotoxicity of SMAC mimetics. Cell Death Dis. 2017;8(8):e2967.

147. Holleman A, Cheok MH, den Boer ML, Yang W, Veerman AJ, Kazemier KM, Pei D, Cheng C, Pui CH, Relling MV, Janka-Schaub GE, Pieters R, Evans WE. Gene-expression patterns in drug-resistant acute lymphoblastic leukemia cells and response to treatment. N Engl J Med. 2004;351(6):533-42.

148. Robinson BW, Behling KC, Gupta M, Zhang AY, Moore JS, Bantly AD, Willman CL, Carroll AJ, Adamson PC, Barrett JS, Felix CA. Abundant antiapoptotic BCL-2 is a molecular target in leukaemias with $t(4 ; 11)$ translocation. Br J Haematol. 2008;141(6):827-39.

149. Bonapace L, Bornhauser BC, Schmitz M, Cario G, Ziegler U, Niggli FK, Schäfer BW, Schrappe M, Stanulla M, Bourquin JP. Induction of autophagydependent necroptosis is required for childhood acute lymphoblastic leukemia cells to overcome glucocorticoid resistance. J Clin Invest. 2010;120(4):1310-23.

150. Hilden JM, Dinndorf PA, Meerbaum SO, Sather H, Villaluna D, Heerema NA, McGlennen R, Smith FO, Woods WG, Salzer WL, Johnstone HS, Dreyer Z, Reaman GH, Children's Oncology Group. Analysis of prognostic factors of acute lymphoblastic leukemia in infants: report on CCG 1953 from the Children's Oncology Group. Blood. 2006;108(2):441-51.

151. Urtishak KA, Edwards AY, Wang LS, Hudome A, Robinson BW, Barrett JS, Cao K, Cory L, Moore JS, Bantly AD, Yu QC, Chen IM, Atlas SR, Willman CL, Kundu M, Carroll AJ, Heerema NA, Devidas M, Hilden JM, Dreyer ZE, Hunger SP, Reaman $\mathrm{GH}$, Felix CA. Potent obatoclax cytotoxicity and activation of triple death mode killing across infant acute lymphoblastic leukemia. Blood. 2013;121(14):2689-703.

152. Kaushik V, Yakisich JS, Kumar A, Azad N, lyer AKV. Ionophores: Potential Use as Anticancer Drugs and Chemosensitizers. Cancers (Basel). 2018;10(10):360.

153. Bedford L, Lowe J, Dick LR, Mayer RJ, Brownell JE. Ubiquitin-like protein conjugation and the ubiquitin-proteasome system as drug targets. Nat Rev Drug Discov. 2011;10(1):29-46.

154. Moriwaki K, Chan FK. Regulation of RIPK3- and RHIM-dependent Necroptosis by the Proteasome. J Biol Chem. 2016;291(11):5948-59. 
155. Rai KR, Chiorazzi N. Determining the clinical course and outcome in chronic lymphocytic leukemia. N Engl J Med. 2003;348(18):1797-9.

156. Rozovski U, Hazan-Halevy I, Keating MJ, Estrov Z. Personalized medicine in CLL: current status and future perspectives. Cancer Lett. 2014;352(1):4-14.

157. Loeder S, Zenz T, Schnaiter A, Mertens D, Winkler D, Döhner H, Debatin KM, Stilgenbauer S, Fulda S. A novel paradigm to trigger apoptosis in chronic lymphocytic leukemia. Cancer Res. 2009;69(23):8977-86.

158. Maas C, Tromp JM, van Laar J, Thijssen R, Elias JA, Malara A, KrippnerHeidenreich A, Silke J, van Oers MH, Eldering E. CLL cells are resistant to smac mimetics because of an inability to form a ripoptosome complex. Cell Death Dis. 2013;4:e782.

159. Liu P, Xu B, Shen W, Zhu H, Wu W, Fu Y, Chen H, Dong H, Zhu Y, Miao K, $\mathrm{Xu}$ W, Li J. Dysregulation of TNF alpha-induced necroptotic signaling in chronic lymphocytic leukemia: suppression of CYLD gene by LEF1. Leukemia. 2012;26(6):1293-300

160. Wu W, Zhu H, Fu Y, Shen W, Miao K, Hong M, Xu W, Fan L, Young KH, Liu P, Li J. High LEF1 expression predicts adverse prognosis in chronic lymphocytic leukemia and may be targeted by ethacrynic acid. Oncotarget. 2016;7(16): 21631-43.

161. Roberts AW, Davids MS, Pagel JM, Kahl BS, Purvada SD, Gerecitano JF, Kipps TJ, Anderson MA, Brown JR, Gressick L, Wong S, Dunbar M, Zhu M, Desai MB, Cerri E, Heitner Enschede S, Humerickhouse RA, Wierda WG, Seymour JF. Targeting BCL2 with Venetoclax in Relapsed Chronic Lymphocytic Leukemia. N Engl J Med. 2016;374(4):311-22.

162. Salomoni P, Calabretta B. Targeted therapies and autophagy: new insights from chronic myeloid leukemia. Autophagy. 2009:5(7):1050-1.

163. O'Hare T, Eide CA, Agarwal A, Adrian LT, Zabriskie MS, Mackenzie RJ, Latocha DH, Johnson KJ, You H, Luo J, Riddle SM, Marks BD, Vogel KW, Koop DR, Apgar J, Tyner JW, Deininger MW, Druker BJ. Threshold levels of $A B L$ tyrosine kinase inhibitors retained in chronic myeloid leukemia cells determine their commitment to apoptosis. Cancer Res. 2013;73(11): 3356-70.

164. Ng KP, Hillmer AM, Chuah CT, Juan WC, Ko TK, Teo AS, Ariyaratne PN, Takahashi N, Sawada K, Fei Y, Soh S, Lee WH, Huang JW, Allen JC Jr, Woo XY, Nagarajan N, Kumar V, Thalamuthu A, Poh WT, Ang AL, Mya HT, How GF, Yang LY, Koh LP, Chowbay B, Chang CT, Nadarajan VS, Chng WJ, Than H, Lim LC, Goh YT, Zhang S, Poh D, Tan P, Seet JE, Ang MK, Chau NM, Ng QS, Tan DS, Soda M, Isobe K, Nöthen MM, Wong TY, Shahab A, Ruan X, Cacheux-Rataboul V, Sung WK, Tan EH, Yatabe Y, Mano H, Soo RA, Chin TM, Lim WT, Ruan Y, Ong ST. A common BIM deletion polymorphism mediates intrinsic resistance and inferior responses to tyrosine kinase inhibitors in cancer. Nat Med. 2012;18(4):521-8.

165. Costa FB, Cortez AP, de Ávila RI, de Carvalho FS, Andrade WM, da Cruz AF, Reis KB, Menegatti R, Lião LM, Romeiro LAS, Noël F, Fraga CAM, Barreiro EJ, Sanz G, Rodrigues MF, Vaz BG, Valadares MC. The novel piperazinecontaining compound LQFM018: Necroptosis cell death mechanisms, dopamine D4 receptor binding and toxicological assessment. Biomed Pharmacother. 2018;102:481-93.

166. Polyak K, Xia Y, Zweier JL, Kinzler KW, Vogelstein B. A model for p53-induced apoptosis. Nature. 1997;389(6648):300-5.

167. Liu J, Peng L, Niu T, Wu Y, Li J, Wang F, Zheng Y, Liu T. PIG7 promotes leukemia cell chemosensitivity via lysosomal membrane permeabilization. Oncotarget. 2016;7(4):4841-59.

168. Philipp S, Sosna J, Plenge J, Kalthoff H, Adam D. Homoharringtonine, a clinically approved anti-leukemia drug, sensitizes tumor cells for TRAlLinduced necroptosis. Cell Commun Signal. 2015;13:25.

\section{Ready to submit your research? Choose BMC and benefit from}

- fast, convenient online submission

- thorough peer review by experienced researchers in your field

- rapid publication on acceptance

- support for research data, including large and complex data types

- gold Open Access which fosters wider collaboration and increased citations

- maximum visibility for your research: over $100 \mathrm{M}$ website views per year

At BMC, research is always in progress.

Learn more biomedcentral.com/submissions 